\title{
Antecedents and Outcomes of Emotional Labour in Hospitality and Tourism:
}

\section{A Meta-Analysis}

\section{Shi $\mathrm{Xu}^{*}$}

University of Surrey

Zheng Chris Cao

Aston University

Yuanyuan Huo

University of Surrey

\begin{abstract}
This paper meta-analytically investigates a theoretical framework of emotional labour and its antecedents and outcomes in the hospitality and tourism literature with 57 correlation matrices from published journal papers. Adopting the psychometric meta-analytical methods and meta-structural equation modelling (meta-SEM) methods, the study finds that emotional labour is related to antecedents including personality, emotional intelligence, customer orientation, social support and display rules, as well as related to attitudinal, behavioural, and customer-related outcomes. In addition, strain mediates the relations between emotional labour and its outcomes. This paper is the first meta-analysis on the relations between emotional labour and the antecedents and outcomes in hospitality and tourism management.
\end{abstract}

Keywords: meta-analysis; emotional labour; antecedents; outcomes; strain.

\footnotetext{
* Corresponding author.
} 


\section{Antecedents and Outcomes of Emotional Labour in Hospitality and Tourism:}

\section{A Meta-Analysis}

\section{Introduction}

The hospitality and tourism industry is characterised as being labour-intensive and it involves unusual working hours and high workload (Tsaur \& Tang, 2012). As part of their daily work, hospitality employees need to interact with others, essentially the customers. During these interactions, the employees have to perform emotional labour, which is referred to "the management of feeling to create a publicly observable facial and bodily display" (Hochschild, 1983, p. 7). Managing emotions is part of organisational rules because organisational decision makers and employees believe that expressing and suppressing certain emotions help facilitate greater performance. Healthy interactions between employees and customers are a core aspect of organisational psychology and marketing literature (Payne \& Frow, 2005). Subsequently, this line of research has increased initiatives from employers and policy makers aiming at managing employee emotions and enhancing their well-being (Grandey \& Melloy, 2017). A better and more integrated understanding of emotional labour is useful to identify additional approaches to managing employee emotions. Correspondingly, it is vital to have a comprehensive picture of the factors that cause and result from emotional labour and provide directions for future research and applications in managing employee emotions.

For researchers to build an extensive framework of emotional labour and develop a cohesive body of research, conceptually elaborating and empirically examining the existing literature is imperative (Humphrey, Ashforth, \& Diefendorff, 2015). Given the accumulation of this line of research, the purpose of the current paper is to investigate the antecedents and 
outcomes of emotional labour in the hospitality and tourism industry through statistically integrating the previous findings by using a comprehensive, theory-driven meta-analysis.

Specifically, this paper (a) presents a theoretically sound framework of the antecedents and outcomes of emotional labour; (b) examines the hypotheses proposed in the framework with an accretion of emotional labour studies in hospitality and tourism, (c) examines the psychological mechanisms linking emotional labour and its outcomes, with strain as a mediator. We identify important theories used to define emotional labour and explain the relations between emotional labour and related constructs. The core set of theories provides guidance for research in this area and fosters accumulation and advancement of research in the study of employee emotional labour (Grandey \& Melloy, 2017). Based on the relevant theories and the 57 correlation matrices in published papers, our conceptual framework and empirical metaanalysis build clarity around the construct of emotional labour as a foundation for researchers to develop more solid and innovative studies on this burgeoning topic in the future.

\section{Literature Review and Hypotheses}

\section{Emotional Labour}

In the past few decades, increasing research attentions have been paid on how service providers display emotions to customers during the service interactions, and how organisations seek to monitor those emotional displays (e.g., Grandey \& Melloy, 2017; Hülsheger \& Schewe, 2011). Displaying organisationally expected emotions to the customers involves a pattern of labour, which requires service providers to expend their effort to do the job (Hochschild, 1983). Triggered by the development in research activity on this topic, the definitions of emotional labour and corresponding inventories have become further differentiated with regards to different acting strategies (Grandey, 2000). The existing literature has identified two forms of emotional labour strategies, including surface acting and deep acting. While surface acting is 
about faking the expected emotions, deep acting involves actually feeling and experiencing the expected emotions (Grandey, 2000). These two distinct dimensions require distinct resources, because surface acting implicates "going through the motions," while deep acting involves "putting oneself in other's shoes" and entails attempts to actually experience the desired emotion (Lam \& Chen, 2012). Generally, service providers have to display organisationallyexpected emotions in the service transactions, disregarding whether they engage in surface acting or deep acting.

When employees put on a happy but disingenuous face, they experience tension when they realise they should display emotions different from their authentic emotions (Xu, Martinez, \& Lv, 2017a). This experience could be particularly draining and uncomfortable for employees, and organisations also begin to experience problems such as employee burnout and turnover, due to the physiological and psychological demands of emotion regulation and the associated emotional dissonance (e.g., Jung \& Yoon, 2014; Krannitz, Grandey, Liu, \& Almeida, 2015). This supports conservation of resources (COR, Hobfoll, 1989) model, which posits that individuals strive to gain, protect, and preserve resources as much as they can. Resource depletion due to surface acting could result in negative outcomes (Krannitz et al., 2015).

Nevertheless, deep acting involves attempting to change internal emotions to match the requirements of the situation (e.g., a depressed front desk employee tries to cheer him/herself up before starting the shift). Although deep acting requires cognitive effort, it restores resources by reducing the discrepancy between internal feelings and external expressions and developing the likelihood of a positive interaction (Xu et al., 2017a). Therefore, when employees perform deep acting, it buffers them from negative mood and results in more positive emotional experience (Grandey, 2003). Deep acting develops positive resources for employees overtime, because the outcomes of deep acting involve restoration of positive emotions and enhanced satisfaction. 
This paper links two emotional labour strategies (i.e., surface acting and deep acting) to their respective antecedents and outcomes through various theories. This paper disentangles antecedent constructs into categories of individual or dispositional factors (including personality, emotional intelligence and customer orientation) and organisational or contextual factors (including social support and display rules). Outcome variables include employee attitudinal outcomes (job satisfaction, organisational commitment and turnover intentions), employee behavioural outcomes (service performance, organisational citizenship behaviour, counterproductive workplace behaviour, creativity, and customer-oriented behaviour), and customer-related outcomes (tips received and customer satisfaction). In addition, strain is investigated as a mediator between emotional labour and outcomes. This paper provides a finegrained examination of these factors.

\section{Antecedents of emotional labour}

\section{Personality}

Personality is defined as the organisation of mental structures and coordination of mental processes that could determine ones' perceptual and behavioural responses to the surrounding environment (Michel et al., 2011). Within the emotional labour literature in hospitality and tourism, extraversion and neuroticism have received adequate empirical attention in the literature to allow for examination in meta-analysis and those two personality traits have shown to be related to employee emotions (Bono \& Vey, 2007; Rusting \& Larsen, 1997). Extraversion is associated with traits such as being sociable, talkative and active, while neuroticism is associated with characteristics such as worry, nervousness and tendency to experience distress (Barrick \& Mount, 1991; Erdheim et al., 2006). Extraversion and neuroticism are proposed as the antecedents of emotional labour because those two constructs tend to have a strong influence on how employees manage emotions at workplace (Kim, 2008). 
Broaden-and-build theory (Fredrickson, 2001) can explain the relation between personality and emotional labour strategies. Based on this theory, when one is high on dispositional positive affectivity, his/her momentary thought-action repertoire can be broadened. Through this process, positive emotions can build up one's personal resources in work situations. Thus, those higher in positive affectivity tend to use their personal resources to improve the functioning; they are more likely to search for solutions and resources to reduce stress and apply the resources to facilitate functioning in their performance. Thus, individuals higher in positive affectivity could experience higher control of the surrounding situations and engage more in deep acting (Grandey, 2000). On the contrary, based on broaden-and-build theory, when an individual is constantly experiencing negative emotions, it narrows his/her thought-action repertoires. Thus, they may seek fewer solutions to help manage demands and expectations from their organisations, which makes them engage more in surface acting (Totterdell \& Holman, 2003).

We use high extraversion as a proxy for positive affectivity and high neuroticism as a proxy for negative affectivity, given the well-replicated relation between extraversion and positive affectivity, and neuroticism and negative affectivity (e.g., Costa \& McCrae, 1980; Scollon \& Diener, 2006). The relationship between extraversion/neuroticism and emotional labour has been demonstrated in several hospitality studies. In an investigation of hospitality and tourism employees in Turkey, Gursoy, Boylu and Avci (2011) demonstrated that neuroticism is positively related to surface acting. Hameed (2016) found that extraversion is positively associated with deep acting while neuroticism is positively associated with surface acting with a sample of hotel employees in Pakistan. Kim (2008) also uncovered the same relations in a sample of frontline employees from the lodging industry in the US. Accordingly, we hypothesise that:

Hypothesis 1a: Neuroticism is positively related to surface acting. Hypothesis 1b: Extraversion is positively related to deep acting. 


\section{Emotional intelligence}

Emotional intelligence refers to one's ability to observe, comprehend, and manage his/her own emotions as well as those of others (Wong \& Law, 2002). Service providers with higher emotional intelligence are more capable to modify feelings to the environment and regulate their emotions appropriately. That is, individuals with higher emotional intelligence can respond sensitively to and accommodate their own and others' emotions (Lee \& Ok, 2012).

Previous studies have argued that emotional intelligence is related to emotional labour. According to Carmeli (2003), emotionally intelligent individuals are adaptive and flexible in regulating their emotions to be consistent with situational demands. They can handle their negative emotions and focus on their positive emotions. Sony and Mekoth (2016) argued that employees with high emotional intelligence are aware of what emotions are (un)expected or (un)acceptable in the interpersonal interactions. Grandey and Melloy (2017) suggested that individuals with high emotional intelligence normally perform deep acting, and they tend to engage in more positive social interactions with customers, such as showing concern, voluntarily helping customers, and they are perceived as good peers since they can comprehend social cues (e.g., emotional expression and behaviour) in communications.

The COR theory (Hobfoll, 1989) suggests that individuals endeavour to keep and manage their personal resources. According to the theory, the amount of employees' resources could impact their choice of emotional labour strategy (Kim, Yoo, Lee, \& Kim, 2012). Based on the availability of their personal resources, employees engage either in surface acting or deep acting to maintain their resources. Employees with rich resources tend to engage in deep acting, while those who lack resources would surface act to minimise resource loss and conserve energy (Liu, Prati, Perrewe, \& Ferris, 2008). Those high in emotional intelligence can perceive others' emotions and turn the emotional resources into needed emotions based on the 
situations. Therefore, they tend to engage in deep acting in performing their jobs (Gabriel, Cheshin, Moran, \& van Kleef, 2016). They can perform emotional labour using emotional intelligence as fundamental resources. They are capable of noticing the positive aspects of expected emotions at work and better controlling their own emotions.

In the hospitality and tourism literature, Kim et al. (2012) demonstrated that emotional intelligence was positively associated with employees' deep acting and negatively related to surface acting strategy in a sample of five-star hotel employees in Korea. Utilising data collected from hotel employees in South China, Wen, Huang and Hou (2019) demonstrated the same results. In addition, in a sample of customer service employees working in fine-dining restaurants in Florida, Kim, Han and Kang (2019) also found that emotional intelligence negatively predicted surface acting and positively predicted deep acting. Thus, we hypothesise the following:

Hypothesis 2a: Emotional intelligence is negatively related to surface acting.

Hypothesis $2 b$ : Emotional intelligence is positively related to deep acting.

\section{Customer orientation}

The pursuit of the "customer is always right" and "customer is God" philosophy is always the priority in the hospitality and tourism industry. This is called customer orientation, which is defined as the service employees' awareness and willingness to satisfy customers' needs, wants and demands via high quality service (Lee, Ok, \& Hwang, 2016). It represents one's pre-disposition to provide courteous and ardent service in service transactions geared towards continuously enhancing service performance (Lee, Ok, Lee, \& Lee, 2018). It is a critical trait that enables employees to carry out jobs and gain access to important information on customer needs. Customer-oriented employees enthusiastically strive to exceed customers' expectations, deal with customers' requests promptly and treat customers politely (e.g., 
Babakus, Yavas, \& Karatepe, 2017). There is a natural fit between employees who are high in customer orientation and the expectations of the service jobs (Lee et al., 2016).

In line with the COR theory (Hobfoll, 1989), employees are striving to preserve resources to cope with stress. Customer orientation is the available energetic resource; employees high in customer orientation are committed to customer service to foster meaningful interactions with customers by showing warmth, empathy and consideration (e.g., Smith et al., 2012). Therefore, they tend to regulate their internal feelings and display the required emotions, and are less likely to act superficially in service transactions (Wu \& Shie, 2017). In the hospitality and tourism context, for example, Smith et al. (2012) found that restaurant employees with higher levels of customer orientation are more likely to adopt deep acting. Lee et al. (2016) demonstrated that customer orientation is positively associated with deep acting and negatively associated with surface acting with a sample of US hotel employees. Wu and Shie (2017) also confirmed the same direction of relationship using hotel employees in China. Thus, we hypothesise that:

Hypothesis 3a: Customer orientation is negatively related to surface acting.

Hypothesis 3b: Customer orientation is positively related to deep acting.

\section{Social support}

Social support refers to the instrumental aid, emotional concern, or informational inputs from the others that can strengthen one's feelings of self-importance and help improve the quality of relationships (Carlson \& Perrewe, 1999). Social support could include various sources including coworkers, the direct supervisor, and the organisation. The relationship between social support and emotional labour can be illustrated by affective event theory (AET, Weiss \& Cropanzano, 1996). AET and supporting empirical evidence suggest that emotions are a dynamic function of a relevant event or experience (Griffin \& Clarke, 2011; Weiss \& Cropanzano, 1996). Specifically, AET suggests that emotional and behavioural outcomes are 
responses to workplace events. An initial evaluation of workplace event shapes one's emotional reaction, which in turn shapes affective states and behaviours. Therefore, perceived social support can be a strong predictor of using different emotional labour strategies, which functions as a proximal source of affective reactions, perceptions, and behaviours (Weiss \& Cropanzano, 1996). Service employees' affective experiences about the extent to which their organisations, supervisors, and coworkers care for them have been the key factor in impacting the choice of different emotional labour strategies (e.g., Hur, Moon, \& Jun, 2013).

Social support can deliver advice, comfort, and concern to buffer employees against stressful events (Lam \& Chen, 2012). Support could include communicating constructive feedback and providing assistance to enable employees to complete the job, at the same time expressing empathy and caring about the needs of employees. If social support is high, service providers would perceive being treated fairly and respectfully, thus they are more able to handle the challenges or stress in the workplace. Hospitality research has suggested that social support prompts service providers to engage in less surface acting and more deep acting during service interactions (e.g., Lam \& Chen, 2012). Social support can trigger corresponding positive affective reactions (Reeck, Ames, \& Ochsner, 2016). If employees' emotion is well attuned to the display rules, they will be inspired to experience the expected emotions, which, in essence, is deep acting (Grandey, 2000). Therefore, we hypothesise that higher levels of social support lead employees to perform deep acting, while lower levels of social support lead them to fake their emotions through surface acting.

Hypothesis 4a: Social support is negatively related to surface acting. Hypothesis 4b: Social support is positively related to deep acting.

\section{Display rules}

Organisational display rules can highly regulate expected employee expression and influence emotional labour. Service occupations have strong norms and expectations on 
emotional displays (Hochschild, 1983). The literature has claimed that display rules is related to emotional acting (Grandey \& Melloy, 2017). Studies have distinguished display rules to positive and negative ones: positive display rules refer to employees' "perceptions of expressing positive emotions" while negative display rules refer to "the perceptions of suppressing negative emotions" in the workplace (Kim, 2008, p. 153). Diefendorff, Croyle, and Gosserand's (2005) results showed that higher positive display rules are related to higher deep acting, and higher negative display rules are related to higher surface acting. They interpreted that positive rules ("what to express") define expectations better and contribute to "acting in good faith" (i.e., deep acting), while negative rules ("what not to express") make service providers just go through the motions and "act in bad faith" (i.e., surface acting).

In hospitality and tourism organisations, clear norms (e.g., showing friendly smiles and upbeat energy) are normally in the job description and service providers are trained accordingly (Kim, 2008). Theoretically, it is logical that different display rules increase the probability of employees' different emotional regulation strategies, resulting in either surface acting or deep acting. Thus, in line with Diefendorff et al. (2005), it is predicted that positive display rules lead to deep acting, and negative display rules lead to surface acting. That is, when organisations ask employees to display positive emotions (e.g., cheerful greetings), they proactively try to experience the positive emotions. In contrast, when employees are required to hide negative feelings (e.g., suppressing distress or anger), they might just pretend not to display those emotions. Therefore, we hypothesise that:

Hypothesis 5a: Positive display rules are positively related to deep acting. Hypothesis 5b: Negative display rules are positively related to surface acting.

\section{Outcomes of emotional labour}

Employee attitudinal outcomes 
Employee attitudinal outcomes are the consequences of emotional labour that are related to how employees feel toward their organisation, which include job satisfaction, turnover intentions, and organisational commitment. Job satisfaction is the most frequently investigated employee attitudinal outcome of emotional labour (Gursoy et al., 2011; Lee \& Ok, 2012; Lee et al., 2016) and the COR theory (Hobfoll, 1989) is the most pervasively used theory to explain the link between emotional labour and job satisfaction. Based upon the COR theory, engaging in surface acting necessitates the expenditure of resources given that it involves the suppression of emotions (Brotheridge \& Lee, 2002). Distress could occur when employees lose resources, which impacts their attitudes toward the job (Grandey, 2000). Employees might think about leaving their current company to preserve their limited resources, if they believe that they cannot deal with the challenges arising from surface acting. Due to drained resource, surface acting could create a desire to escape and even quit the job (Xu et al., 2017a). In contrast, deep acting entails trying to feel positive internally, yielding authentic and positive emotional displays. According to COR theory, hospitality and tourism researchers have found that surface acting is negatively related to attitudinal outcomes including job satisfaction, organisational commitment and intent to remain, and deep acting is positively related to those outcomes (e.g., Kim \& Back, 2012; Wu, Shie, \& Gordon, 2017).

Lee and Ok (2012) used facial feedback hypothesis (Adelmann \& Zajonc, 1989) to analyse the effect of emotional labour strategies on job satisfaction. The hypothesis suggests that positive emotions displayed by a service provider would make customers experience positive emotions, which in turn generate positive reactions and the subsequent job satisfaction of the service provider. When an employee engages in deep acting, the customer can detect the positive and sincere emotions of the employee. The customer can then give the employee positive response accordingly, which makes the employee frequently experience good moods in the workplace. 
Other scholars used the AET framework (Weiss \& Cropanzano, 1996) to explain the link between emotional labour and employee attitudinal outcomes (e.g., Lam \& Chen, 2012). AET argues that affective experiences have effects on individuals' evaluative judgments about their jobs and work environments (positive and negative emotions). Employees will then perform surface acting or deep acting, which are affect-driven behaviours, during service interactions. These affect-driven behaviours, in turn, can contribute to their levels of attitudes toward the job (Lam \& Chen, 2012). Therefore, the following hypotheses were proposed:

Hypothesis 6: Surface acting is negatively related to job satisfaction (a) and organisational commitment $(b)$, and is positively related to turnover intentions $(c)$.

Hypothesis 7: Deep acting is positively related to job satisfaction (a) and organisational commitment (b), and is negatively related to turnover intentions (c).

\section{Employee behavioural outcomes}

Emotional labour strategies also have various impact on employees' behavioural outcomes. This paper considers service performance, creativity, customer-oriented behaviour, organisational citizenship behaviour (OCB), and counterproductive workplace behaviour (CWB) as indicators of the key outcomes that have been investigated in primary studies on this topic.

Surface acting normally leads to negative behavioural outcomes. Surface acting depletes one's mental resources, which may impair employees' task performance. In contrast, deep acting yields authentic emotional displays that would benefit employees' behavioural outcomes. Bakker and Demerouti (2007) proposed the Job Demands-Resources model (JD-R) to theorise how job demands and resources jointly impact employees' behaviours and performance. According to JD-R, performing emotional labour is part of employees' emotional job demands and employees have limited resources (e.g., experience or knowledge) to manage such demands. Therefore, high emotional demands could exhaust employees' resources and decrease service quality (e.g., Karatepe, Haktanir, \& Yorganci, 2010). In contrast, deep acting 
could restore employees' personal resources (e.g., energy or intrinsic motivation) by enhancing positive affect and the likelihood of a positive interpersonal interaction with customers (Côté, 2005). Thus, employees performing deep acting are more energetic and enthusiastic to serve customers, resulting in higher service performance (Chi, Grandey, Diamond, \& Krimmel, 2011). Equivalently, emotional labour strategies not only impact employees' in-role performance, but also their OCBs, or proactive/extra-role performance (e.g., Prentice, Chen, \& King, 2013). Similarly, based on COR, Lee et al. (2018) examined the relation between emotional labour and customer-oriented behaviours among airline employees. They found that surface acting influenced customer-oriented behaviours negatively and deep acting affected customer-oriented behaviours positively.

Furthermore, emotional labour strategies influence employee's creativity. Creativity inherently requires one's motivation in pursuit of new approaches to solve problems and to persistently proceed with changes (Zhou \& George, 2003). This suggests that service providers need to secure sufficient resources and invest a large amount of the resources to develop creative ideas. However, engaging in surface acting could deplete employees' motivational energy, therefore they cannot help neglecting the more challenging aspects of the job, which eventually reduces their levels of creativity (Shin, Hur, \& Oh, 2015). On the contrary, employees performing deep acting can restore their resources to develop creative ideas, which can lead to greater levels of creativity.

Lee and Ok (2014) found that surface acting positively influenced CWB (e.g., service sabotage) among hotel employees. These results were explained using COR theory. Surface acting was conceptualised as a source of CWB because regulating emotions by suppressing expressions depletes resources that can be used to provide service, particularly during difficult interactions. This resource depletion increases the probability of later unethical or counterproductive behaviours (Lee \& Ok, 2014). In contrast, deep acting is expected to 
negatively predict CWB, and in the hospitality literature, Deng, Walter, Lam, and Zhao (2017) found that deep acting is negatively related to employees' ego depletion, which, in turn, indirectly alleviates CWB. Thus, based on the above discussion, we hypothesise that:

Hypothesis 8: Surface acting is negatively related to service performance (a), creativity $(b)$, customer-oriented behaviour (c), and $O C B(d)$, and is positively related to $C W B(e)$.

Hypothesis 9: Deep acting is positively related to service performance (a), creativity $(b)$, customer-oriented behaviour $(c)$, and $O C B(d)$, and is negatively related to $C W B(e)$.

\section{Customer-related outcomes}

In the hospitality and tourism industry, customers' perceived service quality is significantly dependent on the performance of employees (Zhao, Mattila, \& Ngan, 2014). Surface acting involves inauthentic emotional displays, which may be detected by the customers involving in the service interaction, thus surface acting may impair employees' job performance and hinders employee-customer rapport that is key to customer satisfaction (Hülsheger \& Schewe, 2011). Therefore, surface acting may decrease the likelihood of exceeding customers' expectations or receiving large tips. In contrast, deep acting brings in authentic emotional displays that would facilitate interpersonal interactions. Displaying positive moods to customers helps employees communicate important social information to customers and impact customers' attitudes and behaviours (i.e., customer satisfaction and tipping behaviour). Deep-acting employees are more likely to exceed customers' expectations than surface acting, which enhances generosity and tips provided by the customers (Chi et al., 2011).

Building on the emotion as social information model (EASI model; van Kleef, 2009), Hülsheger, Lang, Schewe, and Zijlstra (2015) found that deep acting is positively related to customer tips, based on a sample of Dutch bar and restaurant waiters and taxi-drivers. The EASI model focusses on the interpersonal functions of emotions and argues that emotional 
expressions send key information to observers, which therefore, impact the observers' behaviours through inferential and emotional contagion processes. Deep acting yields authentic emotional displays, and this could facilitate inferential and affective processes and enhance customers' willingness to reward service employees with a higher tip than surface acting. In the hospitality and tourism literature, research has shown that engaging in deep acting elicits more favourable reactions from the customers, helps establish a stronger employee-customer rapport and receive a higher tip than surface acting (e.g., Chi et al., 2011; Hülsheger et al., 2015; Medler-Liraz, 2014). Therefore, we hypothesise that:

Hypothesis 10a: Surface acting is negatively related to customer satisfaction. Hypothesis 10b: Deep acting is positively related to customer satisfaction.

Hypothesis 11: The relationship between deep acting and tipping is stronger than that of surface acting and tipping.

\section{Employee strain}

As aforementioned, according to COR (Hobfoll, 1989), service employees invest a lot of their energy to meet the emotional demands of the job with the expectation of obtaining positive outcomes as a response such as a rewarding relationship with customers, and they may experience strain if the recompense is not followed (Shin et al., 2015). Employees' experienced strain can be manifested in the form of emotional exhaustion, burnout, fatigue, etc. (Nohe, Meier, Sonntag, \& Michel, 2015). Employees performing surface acting usually experience unrewarding encounters with their customers, so they may suffer from strain. In fact, literature has consistently discovered that surface acting leads to strain such as emotional exhaustion or fatigue (e.g., Beal, Trougakos, Weiss, \& Dalal, 2013; Newnham, 2017). In contrast, deep acting produces genuine and authentic displays of emotions (Grandey, 2000). When employees authentically show positive affect via deep acting, customers may respond to them more favourably, restoring the employees' resources and decreasing levels of strain (Xu et al., 2017a). Thus, we hypothesise that surface acting increases strain while deep acting decreases strain. 
Strain could also link emotional labour strategies to a variety of outcomes and Hobfoll's (1989) COR theory was most often used to provide a theoretical explanation to why emotional labour can lead to various outcomes through employee strain. Such an indirect effect is also consistent with stressor-strain-outcomes model (Lazarus, 1966; Koeske \& Koeske, 1993), in which surface acting is a stressor, activating stress arousal, taxing the body and inducing jobbased strain over time, then evoking coping strategies to protect resources, such as quitting and engaging in CWB, etc. Empirical studies in hospitality and tourism literature support those linkages. For example, Kim et al. (2012) examined how emotional labour affects service recovery performance among hotel employees via emotional exhaustion. The findings revealed that surface acting was emotionally exhaustive, which negatively influenced service recovery performance. In contrast, deep acting reduces emotional exhaustion and positively influenced service recovery performance. Lee and Ok (2012) found an indirect effect of surface acting on job satisfaction via emotional exhaustion. In addition, Lv, Xu, Ji (2012) found that emotional exhaustion mediated the relation between surface/deep acting and intention to quit. These studies suggest that employees experience various consequences (e.g., job satisfaction, turnover intentions, service performance, etc.) when performing emotional labour strategies through strain. Thus, we hypothesise the following:

Hypothesis 12a: Surface acting is positively related to strain. Hypothesis 12b: Deep acting is negatively related to strain.

Hypothesis 13: Strain mediates the relation between emotional labour strategies and the outcomes.

The conceptual framework is illustrated in Figure 1, based on the discussion of the literature and hypotheses development.

Insert Figure 1 about here 


\section{Methodology}

\section{Search and inclusion of literature}

This paper performs a meta-analysis of the existing empirical research on the link among emotional labour and the antecedents and outcomes in hospitality related sectors. The authors conducted a search for literature via online databases. The databases included Elsevier Science Direct, Sage, Emerald, Taylor and Fransis, EBSCO and Web of Science. The search terms were a combination of "emotional labour," "emotional labor," "emotional work," "emotional investment," "surface acting," "deep acting," "genuine emotional display," "emotion regulation" and "emotional dissonance," along with "tourism," "hospitality," "hotel," "restaurant," "casino," "cruise" and "airline."

We chose the studies according to four inclusion criteria. First, the study is quantitative by nature and must include surface acting and/or deep acting. Second, the study includes at least one construct that we have conceptualised as an antecedent or outcome in our model. Third, all variables are assessed at the individual level and their correlations are reported. Correlations between study variables that are reported at the individual level were coded. Fourth, the setting of the study is within the hospitality and tourism related sectors. To ensure reliability, the coding was cross checked by the first two authors.

Our search covered all available studies published up to July 2019, which ensures the currency of our literature review while also allows us to capture a relatively long-term development of research on emotional labour in hospitality and tourism sectors. Taking all the inclusion criteria into consideration, our search yielded 63 articles, with 57 useable correlation matrices among them. All the identified studies were examined in terms of the following relevant parameters: authors, year, country, sector, participants, sample size, antecedents, outcomes, and whether the studies used strain as a mediator. The coded characteristics are 
shown in Table 1. These studies are indicated in the reference list with an asterisk before the entry.

Insert Table 1 about here

\section{Analytical methods}

We conduct meta-analyses in order to synthesise the primary empirical findings using statistical tests (Borenstein et al., 2009). Our analysis draws on two advanced methods that have gained increasing popularity in recent years, but their application in the context of hospitality and tourism research is still limited. They are psychometric meta-analysis (Hunter \& Schmidt, 2004) and meta-analytic structural equation modelling (meta-SEM) (Cheung, 2015; Jak, 2015).

Psychometric meta-analysis. The psychometric meta-analytical methods developed by Hunter and Schmidt (2004) are commonly applied to conduct meta-analyses in organisational behaviour and strategic management (e.g., Hülsheger \& Schewe, 2011; Karna, Richter, \& Riesenkampff, 2016). For the purpose of this study, we used the individual-correction metaanalysis (Hunter \& Schmidt, 2004, pp.75-136) to estimate the mean value of correlations between antecedents and outcomes. We coded the correlation matrix and the sample size of each article that we collected. In synthesizing the correlation coefficients between antecedents and outcomes, the psychometric meta-analysis uses sample sizes as weights and adjusts for the sampling variances of the correlations.

Meta-analytic SEM. Meta-analytic structural equation modelling (MASEM, or metaSEM) is popular with applied psychology studies (e.g., Bamberg \& Möser, 2007; Colquitt et al., 2013). It is a technique that pools correlation coefficients of a set of variables from several independent samples, so as to fit structural equation models in the pooled matrix (Jak \& Cheung, 
2018). This method is introduced and reviewed by Cheung (2015), Jak (2015) and Landis (2013). It can synthesise the individual causal links among variables into a single, combined model.

Specifically, we follow the adapted the two-stage structural equation modelling (TSSEM) OC approach described in Jak (2015) and Jak and Cheung (2018). The data used are the individual correlation matrix and the sample size of each article that we collected. The estimation process contains two steps. In the first step, a pooled correlation matrix is estimated, and in the second step, a structural equation model is fitted on this matrix in order to explain the pooled correlations (Jak, 2015, pp.21-30). The OC approach stands for omitted correlation approach. When carrying out the estimation, for each missing correlation coefficient in a study, an arbitrary value (i.e., the average correlation across studies) is plugged in. This approach has been evaluated to perform quite stable across missing data conditions (Jak \& Cheung, 2018).

For the purpose of this study, we adopt the meta-analytic SEM method to test our proposed conceptual model described in Figure 1.

\section{Results}

The empirical results from our psychometric meta-analysis and meta-SEM are reported in Tables 2-3 and Figure 2. Tables 2 and 3 list the correlations synthesised from the literature, and Figure 2 shows the estimation of meta-SEM. We mainly focus on the corrected correlation, $\rho$, in testing our hypothesised antecedents and consequences of emotional labour. A cut-off is used, with an effect size magnitude of $\rho>0.10$ considered as meaningful relationships (Michel et al., 2011). Consistent with Cohen (1988) and Michel et al. (2011), we interpret the strength of correlation $\rho$ as $>0.50=$ strong, $>0.30=$ moderate, and $>0.10=$ small .

Insert Tables 2 and 3 about here 


\section{Hypothesised relationship of emotional labour and antecedents}

We categorise the antecedents into five groups: personality, emotional intelligence, customer orientation, social support, and display rules. Hypotheses 1 predicts that neuroticism is positively associated with surface acting, and extraversion is positively associated with deep acting. Our results support the hypothesis with positive correlation between neuroticism and surface acting $(\rho=0.130)$, as well as between extraversion and deep acting $(\rho=0.211)$. Hypothesis $2 \mathrm{a}$, the negative relationship between emotional intelligence and surface acting is not supported since the correlation is not significant $(\rho=-0.077)$. But emotional intelligence is significantly and positively related to deep acting $(\rho=0.260)$, supporting Hypothesis $2 \mathrm{~b}$. Customer orientation has a negative correlation with surface acting $(\rho=-0.243)$, and a positive correlation with deep acting $(\rho=0.403)$. Therefore, Hypothesis 3 is supported. Hypothesis $4 \mathrm{a}$ is the negative correlation between social support and surface acting, and it is not supported due to the non-significant correlation $(\rho=-0.046)$. The positive relation between social support and deep acting $(\rho=0.205)$ supports Hypothesis $4 \mathrm{~b}$.

For emotional display rules, Hypothesis 5 predicts that positive display rules are positively associated with deep acting, and negative display rules are positively associated with surface acting. Our results show that positive display rules have a positive correlation with deep acting $(\rho=0.427)$, and negative display rules have a positive correlation with surface acting ( $\rho$ $=0.133)$. Thus, Hypothesis 5 is supported.

\section{Hypothesised relationship of emotional labour and outcomes}

We include three categories of consequences of surface acting and deep acting: attitudinal outcomes, behavioural outcomes or performance, and customer-related outcomes. For the attitudinal outcomes, our Hypothesis 6 predicts a negative effect of surface acting on (a) job satisfaction, (b) organisational commitment, and a positive effect of surface acting on (c) turnover intentions. Hypothesis 6 a is supported with negative correlation $(\rho=-0.143)$ and 
Hypothesis $6 \mathrm{c}$ is supported with moderate positive correlation $(\rho=0.386)$. The non-significant correlation between surface acting and organisational commitment $(\rho=-0.072)$ shows that Hypothesis $6 \mathrm{~b}$ is not supported. For deep acting, Hypothesis 7 predicts that it is positively related to (a) job satisfaction and (b) organisational commitment, and negatively related to (c) turnover intentions. The positive relation between deep acting and job satisfaction $(\rho=0.201)$ supports Hypothesis 7a, and the negative relation between deep acting and turnover intentions $(\rho=-0.174)$ supports Hypothesis 7c. Similar as the non-significant correlation between surface acting and organisational commitment, deep acting has no significant correlation with organisational commitment $(\rho=0.054)$. Thus, Hypothesis $7 \mathrm{~b}$ is not supported.

We identified five indictors from literature to capture the behavioural outcomes or performance of emotional labour: (a) service performance, (b) creativity, (c) customer-oriented behaviour, (d) OCB, and (e) CWB. Our results show that surface acting negatively correlates with service performance $(\rho=-0.114)$ and creativity $(\rho=-0.236)$, supporting Hypothesis 8 a and Hypothesis $8 \mathrm{~b}$. Hypothesis $8 \mathrm{e}$ is also supported by the positive correlation between surface acting and CWB $(\rho=0.261)$. Hypothesis $8 \mathrm{c}$ is not supported since we find a non-significant correlation between surface acting and customer-oriented behaviour $(\rho=0.069)$; and Hypothesis $8 \mathrm{~d}$ is not supported from the non-significant relationship between surface acting and OCB $(\rho=0.075)$. Deep acting has a moderate positive correlation with service performance $(\rho=0.255)$ and creativity $(\rho=0.212)$, and a strong positive correlation with customer-oriented behaviour $(\rho=0.559)$, supporting Hypotheses 9a, 9b, and 9c. Hypotheses 9d and 9e are not supported since deep acting is not significantly related to OCB $(\rho=.072)$ and CWB $(\rho=-$ $0.023)$.

Hypothesis 10 is about the correlation between emotional labour and customer satisfaction. The negative correlation between surface acting and customer satisfaction $(\rho=-$ 0.260) supports Hypothesis 10a, and the positive correlation between deep acting and customer 
satisfaction $(\rho=0.362)$ supports Hypothesis 10b. Another customer-related outcome we selected is tips, and the results support our Hypothesis 11 which states that the correlation between deep acting and tips $(\rho=0.264)$ is stronger than that of surface acting and tips $(\rho=$ $0.150)$.

\section{Hypothesised mediating effect of strain}

While Tables 2 and 3 show the direct relations between emotional labour and its antecedents and outcomes, we are also keen to understand the mediating process through which emotional labour results in the various outcomes. By using meta-SEM, we combine casual links in a single model and explore the relationships that do not necessarily have been studied in prior literature. The stressor-strain-outcomes framework (Koeske \& Koeske, 1993) indicates that strain may be a potential mediator in linking the stressors (emotional labour in this study) to our outcome variables.

We therefore examine how emotional labour results in outcomes through strain. The results are presented in Figure 2.

Insert Figure 2 about here

We find that surface acting is positively associated with strain $(\beta=0.336 ; p<0.001)$ and deep acting is negatively associated with strain $(\beta=-0.126 ; p<0.001)$. Thus, Hypothesis 12 is supported. Moreover, Figure 2 shows that surface acting and deep acting can influence the outcomes (i.e., job satisfaction, organisational commitment, turnover intentions, and service performance) in a more complicated way. Strain is positively related to turnover intention $(\beta=0.416 ; p<0.001)$, and negatively related to job satisfaction $(\beta=-0.676 ; p<$ $0.001)$, organisational commitment $(\beta=-0.562 ; p<0.001)$, and service performance $(\beta=-$ 0.367; $p<0.001)$. Therefore, strain mediates the relationship between emotional labour strategies and the outcomes and Hypothesis 13 is supported. We were only able to include four 
outcomes because, for those not included, the number of existing emotional labour studies in the hospitality and tourism literature with strain as a mediator is too small for meta-SEM analysis.

Overall, Table 4 summarises the results of hypotheses testing.

Insert Table 4 about here

\section{Discussion}

This paper is the first meta-analysis of the antecedents and outcomes of emotional labour in the hospitality and tourism industry. With regard to the antecedents, a general pattern we discover in their correlation with emotional labour is that three of them (personality, customer orientation, and emotional display rules) have a stronger correlation with deep acting than with surface acting, and the other two of the antecedents (emotional intelligence and social support) are not correlated with surface acting. The findings indicate that employees engage in surface acting for complicated reasons. For example, on one side, employees high in emotional intelligence may find it easy to take the customers' perspectives, which reduces their needs to resort to surface acting; on the other side, high emotional intelligence employees may also intentionally use surface acting to save their energy and resources. Employees who get more social support may still turn to surface acting frequently because the supportive environment may make them feel safe to use the superficial strategy and they will not be punished even their faked smile is detected by the customers.

In addition, deep acting shows a consistent positive correlation with all our antecedents, which indicates that deep acting is more predictable by hiring extravert, emotionally intelligent, and customer-oriented employees, clearly addressing the positive emotional display rules, and providing social support to employees. We find a positive relationship between negative 
display rules and deep acting. Suppressing negative emotions has been frequently associated with surface acting since telling employees what not to express is likely to evoke employees' response-focused emotional regulation-surface acting (Kammeyer-Mueller et al., 2013). Our finding shows that suppressing negative emotions may not only be linked to faking the desired emotions, it can also serve as a first step before employees change their internal feelings, make themselves happy, and act in good faith when interacting with customers. Thus, our metaanalytical results offer an interesting perspective on negative display rules, which indicates that it can either result in the action of faking positive expressions (Diefendorff, Croyle, \& Gosserand, 2005) or help to eliminate employees' negative feelings and facilitate their change of their real emotions.

With regard to the consequences, as we predict, deep acting shows a positive effect on the attitudinal, behavioural, and customer-related outcomes, with a strong correlation with customer-oriented behaviour. Contrary to our hypothesis, surface acting is not negatively related to customer-oriented behaviour. The reason might be that although employees' true feelings remain unchanged, their action of faking the emotions according to the display rules is also customer-oriented and may meet customers' expectation to some extent (MesmerMagnus, DeChurch, \& Wax, 2012).

We find that both surface acting and deep acting are not related to OCB. This result may be due to the following reasons: first, the job nature of hospitality employees makes it difficult to define in-role and extra-role behaviours (Bienstock, DeMoranville, \& Smith, 2003). Second, although deep acting may create a positive climate which encourages interpersonal helping and extra contribution to the organisation, it might also consume employees' resources which could be used for OCB; for surface acting, it may become a habitual behaviour which is not necessarily associated with depleting employees' resources for OCB. In addition, the construct of OCB consists different dimensions, including behaviours toward individuals 
(altruism and courtesy) and behaviours toward the organisation (civic virtue and sportsmanship) (Hoffman, Blair, Meriac, \& Woehr, 2007). While altruism and courtesy are the intrapersonal behaviours which employees need to truly feel the positive emotions (deep acting) to enact the behaviours, and the resources needed for such behaviours might be depleted by surface acting; the behaviours toward the organisation may be considered as an organisational norm by the employees which they should be engaged in without emotional change (Ramachandran, Jordan, Troth, \& Lawrence, 2011). Similarly, the two types of emotional labour are not related to organisational commitmentt either. Employees' commitment to the organisation may not necessarily involve emotions. They may just treat commitment as a normative behaviour (normative commitment) or commit to the organisation because of high cost associated with leaving (continuance commitment).

On the mediating effect of strain, in the additional meta-SEM analysis, we find that emotional labour strategies lead to employee strain, which in turn, predict various outcomes. This is consistent with previous findings in literature. For example, Prati, Liu, Perrewé and Ferris (2009) found that emotional labour is positively related to strain. Chen et al. (2012) also showed that strain mediated the effect of emotional labour on work performance. Although emotional labour is not significantly related to organisational commitment, its indirect effect on organisational commitment through strain becomes significant. That is, as a stressor in workplace, its potential association with strain might be attenuated by other factors (e.g., personality, supervisor or peer support). But in case the resource loss from emotional labour cannot be offset and strain is induced, employees' overall commitment to the organisation will be destroyed (Ramachandran et al., 2011).

\section{Theoretical implications}

The present study contributes to emotional labour literature in hospitality and tourism management in the following ways. First, this paper provides a comprehensive, theory-driven 
meta-analysis on the predictors, as well as costs and benefits of emotional labour by statistically testing the key dispositional and organisational contextual antecedents, the attitudinal, behavioural, and customer-related outcomes of emotional labour, as well as the mediating role of strain in the relation between emotional labour and the outcomes. The meta-analysis allows for a finer grained examination of the previously proposed antecedents and outcomes of emotional labour, and additional analyses on how emotional labour leads to the outcome variables. Although research in emotional labour has grown rapidly, the findings in extant studies have been mixed and inconsistent (Kammeyer-Mueller et al., 2013). As the first metaanalysis of emotional labour in hospitality and tourism, our research contributes to literature by clarifying the consistent results and the consensus which have been reached in existing literature, underlining the inconsistent findings and interpretations, and establishing a strong empirical foundation for future scholars to improve the existing framework or to look for more dynamic theoretical frameworks.

Second, we contribute to various theories related to emotional labour by providing further empirical confirmation and highlighting the gaps of current research. The positive correlations we find between neuroticism and surface acting, and between extraversion and deep acting, show the effectiveness of broaden-and-build theory in the emotional labour context. The positive effect of emotional intelligence and customer orientation on deep acting and the negative effect of customer orientation on surface acting further confirm COR theory by highlighting emotional intelligence and customer orientation as personal resources that can help facilitate employees' deep acting. The proximal (strain) and distal (attitudinal, behavioural, and customer-related outcomes) effects of emotional labour strategies provide additional support the application of COR theory in emotional labour literature. Deep acting has been consistently showed to enhance people's resources, and thereby reduce strain and lead to positive outcomes; while surface acting depletes resources, creates strain, and leads to negative 
outcomes. The consistent empirical support for broaden-and-build theory and COR theory we find in this meta-analysis suggests that future research can introduce and test more relevant predictors and outcomes of emotional labour based on these theories. We also confirm AET theory in emotional labour by considering social support as the affective event that induces affect-driven behaviours (surface acting and deep acting), and further impacts employees' attitudinal and behavioural outcomes. However, no study from hospitality and tourism journals has investigated discrete emotions as a function in employee-customer interactions. This represents a research gap as AET suggests that events/work-related situations lead to discrete emotions (e.g. joy or fear), which in turn could influence one's emotional labour strategy.

Third, the counterintuitive findings from our analysis may have significant implications for the measurement of deep acting and surface acting. We surprisingly find a positive relationship between negative display rules and deep acting, as well as a nonsignificant relationship between the two emotional labour strategies and organisational commitment and OCB. While we have explained the possible reasons for these interesting results, the measurement of emotional labour might be another explanation. Both deep acting and surface acting can be used by service employees to amplify their positive emotions and supress their negative emotions (Holman, Martınez-Inigo, \& Totterdell, 2008); while the current measurement of deep acting and surface acting does not distinguish between amplification and suppression. The negative display rules may have a different relationship with deep acting by amplifying the positive emotions from deep acting by supressing the negative emotions; and amplification and suppression may have different impacts on OCB and organisational commitment. Therefore, our meta-analysis indicates that developing a more fine-grained measurement of deep acting and surface acting might help to explain the inconsistent findings.

\section{Practical implications}


This paper also provides implications for practitioners. First of all, this paper suggests that hospitality and tourism practitioners investing in selecting and training employees could have positive impacts. For example, given their positive effect on deep acting, extraversion, emotional intelligence and customer orientation can be the preferred qualities that organisations in hospitality and tourism industry look for in a candidate during recruitment. Our metaanalysis on the antecedents of emotional labour shows that customer orientation and positive emotional display rule has a moderate to strong correlation with deep acting while all other correlations are considered as small to moderate, according to Cohen's (1988) rule of thumb. The significant effect of positive display rules is in line with the findings of prior research which suggests that emotional labour can be trained (Grandey, 2003).

Furthermore, organisations should strengthen employees' awareness of the display rules by explicitly communicating the expectation and standard, and such expectation may be enforced through supervision. The significant correlation between social support and deep acting in our meta-analysis shows that supervisor and peer support should be encouraged, especially in hospitality and tourism organisations. The support employees get from the organisations may play a contagious role for motivating employees to engage in deep acting with customers. For example, a supportive climate with considerate, respect, and socioemotional support among the organisation can be contagious to employees' sincere attitude and deep acting in interacting with customers (Ortiz-Bonnín, García-Buades, Caballer, \& Zapf, 2016). Moreover, organisations can suggest both supervisor and coworkers to provide positive feedback to one another, and such positive feedback can be considered as a kind of resource for promoting deep acting (Yoo \& Arnold, 2015). In addition, pairing employees with a supervisor or peer mentor may help employees better recognise the necessity and better understand the skills of deep acting. 
Finally, our findings show that deep acting and surface acting should be differentiated by researchers and practitioners. We found a positive effect of deep acting on the outcome variables, which is consistent with the existing theoretical framework and empirical studies in the field (Hülsheger \& Schewe, 2011). Although surface acting is found to be positively related to customer-orientation behaviour and tips, it shows a negative correlation with most of the beneficial outcomes (e.g., job satisfaction, service performance, creativity, customer satisfaction), and a positive correlation with turnover intention and CWB. Therefore, surface acting is ineffective and is normally detrimental to employees, organisations, and customers. Hospitality and tourism organisations should promote deep acting among their service employees. Organisations may not only require employees to display certain emotions, but also help employees to adjust their inner feelings. Training on the philosophy of "service with a real smile" needs to be implemented to help employees better understand customers' needs and expectations. Employees can also be advised that deep acting not only benefits customers through good service, but also improves their own service quality and well-being. In addition, we have also identified a mediating role of strain in the relationship between emotional labour and outcomes. This suggests that organisations could use intervening mechanisms, such as regularly encouraging meditative breaks (Richardson \& Rothstein, 2008) and mindfulnessbased stress reduction programmes (Grossman et al., 2004), to help employees reduce their strain, which would improve service quality and enhance employee well-being.

\section{Limitations and directions for future research}

Although the current study offers a number of important insights into emotional labour in the hospitality and tourism industry, the following limitations should be taken into account when drawing conclusions from our paper. First, we use the traditional categorisation of surface acting and deep acting for emotional labour to get enough sample empirical studies to conduct our meta-analysis. Despite the recent progress in introducing the genuine expression of 
emotions as third type of emotional labour, only very few empirical studies in hospitality has included this dimension (Nart et al., 2019). Future meta-analysis in emotional labour, when genuine emotional expression has been examined more extensively, may include it as an emotional labour strategy and investigate its antecedents and consequences. Moreover, emotional labour may not be a dichotomous variable and future theoretical and empirical research may take into consideration the possible co-occurrence of surface acting and deep acting.

Second, most of the primary studies in our meta-analysis are cross-sectional surveys with self-reported data. Therefore, our meta-analysis results might be inflated by common method bias (Podsakoff et al., 2003) and we cannot make causal inferences about the antecedents and outcomes of emotional labour. The reversed causality from the consequences to emotional labour or from emotional labour to the antecedents is possible. For example, a reverse effect that job satisfaction leads to more deep acting is possible. We thereby call for more longitudinal study in hospitality industry to show the causal pathways from antecedents to emotional labour and from emotional labour to outcome variables. In addition, we encourage future researchers to collect information on customer-rated performance to make the findings more solid and convincing.

Third, we have not included moderators in our analysis. The nonsignificant correlation between emotional labour and some variables (e.g., emotional intelligence and surface acting, social support and surface acting, etc.) indicates that there might be some important contextual variables that can moderate the relationship we examined, or variables such as emotional intelligence and social support may be the potential moderators. A couple of research in emotional labour has incorporated contextual factors such as supervisory support and personorganisation fit in studying the extent to which the antecedents influence emotional labour and emotional labour influences outcomes (e.g., Chen et al., 2012; Lam, Huo, \& Chen, 2018). 
Future research is encouraged to investigate the potential contextual factors that may impact the relationships in our proposed theoretical framework, including service climate, leadership, employees' coping style, etc.

Finally, although we are able to conduct meta-analysis to test an integrated framework on emotional labour by aggregating and evaluating the correlations from various studies, only a small number of studies are available for some of our study variables (e.g., tips and customer satisfaction). The limited number of studies may impact the accuracy of meta-analytic estimates. However, according to Schmidt et al. (1985), even meta-analyses with small number of studies could help us to gain meaningful and insightful ideas into the relationships among constructs and are worthwhile being conducted (see also Hülsheger and Schewe, 2011; Valentine et al., 2010).

\section{Conclusion}

In conclusion, based on a meta-analysis of 57 usable correlation matrices published in journals until 2019, this paper confirms the significant effect of personality, emotional intelligence, customer orientation, social support, and display rules on emotional labour strategies, as well as the effect of emotional labour strategies on the attitudinal, behavioural, and customer-related outcomes. In addition, strain is demonstrated to mediate the relationship between emotional labour strategies and the various outcomes. Our meta-analysis shows the individual and contextual causes of emotional labour, as well as the potential beneficial effect of deep acting and detrimental effect of surface acting, which has significant theoretical and practical implications for scholars and managerial professionals in hospitality and tourism industry. 


\section{Reference}

References noted with “*” are included in the meta-analysis.

*Abbas, T., Mansour, N., \& Elshawarbi, N. (2018). Examining to what extent do employees express emotional labor: An application on front-office department in five-star hotels in Cairo. Journal of the Faculty of Tourism and Hotels-University of Sadat City, 2(2).

Adelmann, P. K., \& Zajonc, R. B. (1989). Facial efference and the experience of emotion. Annual Review of Psychology, 40(1), 249-280.

*Aziza, N. A., Najafia, B., Shamsudinb, F. M., \& Alshuaibi, A. S. I. (2016). Customer Perception of Emotional Labor of Airline Service Employees and Customer Loyalty Intention. Paper presented at the ISSC 2016: International Soft Science Conference. http://dx.doi.org/10.15405/epsbs.2016.08.86

Babakus, E., Yavas, U., \& Karatepe, O. M. (2017). Work engagement and turnover intentions: Correlates and customer orientation as a moderator. International Journal of Contemporary Hospitality Management, 29(6), 1580-1598.

Bakker, A. B., \& Demerouti, E. (2007). The job demands-resources model: State of the art. Journal of Managerial Psychology, 22(3), 309-328.

Bamberg, S., \& Möser, G. (2007). Twenty years after Hines, Hungerford, and Tomera: A new meta-analysis of psycho-social determinants of pro-environmental behaviour. Journal of Environmental Psychology, 27(1), 14-25.

Barrick, M., \& Mount, M. (1991). The big five personality dimensions and job performance: A meta-analysis. Personnel Psychology, 44(1), 1-26.

*Beal, D. J., Trougakos, J. P., Weiss, H. M., \& Dalal, R. S. (2013). Affect spin and the emotion regulation process at work. Journal of Applied Psychology, 98(4), 593-605.

Bienstock, C. C., DeMoranville, C. W., \& Smith, R. K. (2003). Organizational citizenship behavior and service quality. Journal of Services Marketing, 17(4), 357-378.

Bono, J. E., \& Vey, M. A. (2007). Personality and emotional performance: Extraversion, neuroticism, and self-monitoring. Journal of Occupational Health Psychology, 12(2), 177-192.

Borenstein, M., Hedges, L.V., Higgins, J.P.T., \& Rothstein, H.R. (2009). Introduction to MetaAnalysis. Chichester: Wiley.

*Bozionelos, G. (2016). Emotion work in the Arab context: Its relationship to job satisfaction and the moderating role of trust to the employer. Psychological Reports, 119(1), 136-153. 
Brotheridge, C. M., \& Lee, R. T. (2002). Testing a conservation of resources model of the dynamics of emotional labor. Journal of Occupational Health Psychology, 7(1), 57-67.

*Bujisic, M., Wu, L., Mattila, A., \& Bilgihan, A. (2014). Not all smiles are created equal: Investigating the effects of display authenticity and service relationship on customer tipping behavior. International Journal of Contemporary Hospitality Management, 26(2), 293-306.

Carlson, D. S., \& Perrewé, P. L. (1999). The role of social support in the stressor-strain relationship: An examination of work-family conflict. Journal of Management, 25(4), 513-540.

Carmeli, A. (2003). The relationship between emotional intelligence and work attitudes, behavior and outcomes: An examination among senior managers. Journal of Managerial Psychology, 18(8), 788-813.

*Chen, K. Y., Chang, C. W., \& Wang, C. H. (2019). Frontline employees' passion and emotional exhaustion: The mediating role of emotional labor strategies. International Journal of Hospitality Management, 76, 163-172.

*Chen, Z., Sun, H., Lam, W., Hu, Q., Huo, Y., \& Zhong, J. A. (2012). Chinese hotel employees in the smiling masks: Roles of job satisfaction, burnout, and supervisory support in relationships between emotional labor and performance. The International Journal of Human Resource Management, 23(4), 826-845.

Cheung, M.W.L. (2015). Meta-Analysis: A Structural Equation Modeling Approach. John Wiley \& Sons.

*Chi, N. W., \& Grandey, A. A. (2019). Emotional labor predicts service performance depending on activation and inhibition regulatory fit. Journal of Management, 45(2), 673-700.

*Chi, N. W., Grandey, A. A., Diamond, J. A., \& Krimmel, K. R. (2011). Want a tip? Service performance as a function of emotion regulation and extraversion. Journal of Applied Psychology, 96(6), 1337-1346.

*Chi, N. W., \& Wang, I. A. (2018). The relationship between newcomers' emotional labor and service performance: The moderating roles of service training and mentoring functions. The International Journal of Human Resource Management, 29(19), 2729-2757.

*Chu, K. H., Baker, M. A., \& Murrmann, S. K. (2012). When we are onstage, we smile: The effects of emotional labor on employee work outcomes. International Journal of Hospitality Management, 31(3), 906-915. 
Cohen, J. (1988). Statistical Power Analysis for the Behavioral Sciences (2nd ed.). Mahwah, NJ: Erlbaum.

*Collishaw, M. A., Dyer, L., \& Boies, K. (2008). The authenticity of positive emotional displays: Client responses to leisure service employees. Journal of Leisure Research, 40(1), 23-46.

Colquitt, J. A., Scott, B. A., Rodell, J. B., Long, D. M., Zapata, C. P., Conlon, D. E., \& Wesson, M. J. (2013). Justice at the millennium, a decade later: A meta-analytic test of social exchange and affect-based perspectives. Journal of Applied Psychology, 98(2), 199-236.

Costa, P. T., \& McCrae, R. R. (1980). Influence of extraversion and neuroticism on subjective well-being: happy and unhappy people. Journal of Personality and Social Psychology, 38(4), 668-678.

Côté, S. (2005). A social interaction model of the effects of emotion regulation on work strain. Academy of Management Review, 30(3), 509-530.

*Deng, H., Walter, F., Lam, C. K., \& Zhao, H. H. (2017). Spillover effects of emotional labor in customer service encounters toward coworker harming: A resource depletion perspective. Personnel Psychology, 70(2), 469-502.

Diefendorff, J. M., Croyle, M. H., \& Gosserand, R. H. (2005). The dimensionality and antecedents of emotional labor strategies. Journal of Vocational Behavior, 66(2), 339357.

Erdheim, J., Wang, M., \& Zickar, M. (2006). Linking the Big Five personality constructs to organizational commitment. Personality and Individual Differences, 41(5), 959-970.

Fredrickson, B. L. (2001). The role of positive emotions in positive psychology: The broadenand-build theory of positive emotions. American Psychologist, 56(3), 218-226.

$* \mathrm{Fu}, \mathrm{Y} . \mathrm{K}$. (2013). The influence of internal marketing by airlines on customer-oriented behavior: A test of the mediating effect of emotional labor. Journal of Air Transport Management, 32, 49-57.

Gabriel, A. S., Cheshin, A., Moran, C. M., \& van Kleef, G. A. (2016). Enhancing emotional performance and customer service through human resources practices: A systems perspective. Human Resource Management Review, 26(1), 14-24.

*Geng, Z., Liu, C., Liu, X., \& Feng, J. (2014). The effects of emotional labor on frontline employee creativity. International Journal of Contemporary Hospitality Management, 26(7), 1046-1064.

Grandey, A. A. (2000). Emotional regulation in the workplace: A new way to conceptualize emotional labor. Journal of Occupational Health Psychology, 5(1), 95-110. 
Grandey, A. A. (2003). When "the show must go on": Surface acting and deep acting as determinants of emotional exhaustion and peer-rated service delivery. Academy of Management Journal, 46(1), 86-96.

*Grandey, A. A., Fisk, G. M., Mattila, A. S., Jansen, K. J., \& Sideman, L. A. (2005). Is “service with a smile" enough? Authenticity of positive displays during service encounters. Organizational Behavior and Human Decision Processes, 96(1), 38-55.

Grandey, A. A., \& Melloy, R. C. (2017). The state of the heart: Emotional labor as emotion regulation reviewed and revised. Journal of Occupational Health Psychology, 22(3), 407-422.

Griffin, M. A., \& Clarke, S. (2011). Stress and well-being at work. In S. Zedeck (Ed.), APA Handbooks in Psychology. APA handbook of industrial and organizational psychology, Vol. 3. Maintaining, expanding, and contracting the organization (pp. 359-397). Washington, DC, US: American Psychological Association.

Grossman, P., Niemann, L., Schmidt, S., \& Walach, H. (2004). Mindfulness-based stress reduction and health benefits: A meta-analysis. Journal of Psychosomatic Research, 57(1), 35-43.

*Gursoy, D., Boylu, Y., \& Avci, U. (2011). Identifying the complex relationships among emotional labor and its correlates. International Journal of Hospitality Management, 30(4), 783-794.

*Hameed, F. (2016). Impact of Personality on Adaptive Performance with Mediating Role of Emotional Labor. Testing a Mediated Moderated Model among Front-line Female Hospitality Industry Employees in Pakistan (Doctoral dissertation, CAPITAL UNIVERSITY).

Hobfoll, S. E. (1989). Conservation of resources: A new attempt at conceptualizing stress. American Psychologist, 44(3), 513-524.

Hochschild, A. R. (1983). The managed heart. Berkeley, CA: University of California Press.

Hoffman, B. J., Blair, C. A., Meriac, J. P., \& Woehr, D. J. (2007). Expanding the criterion domain? A quantitative review of the OCB literature. Journal of Applied Psychology, 92(2), 555-566.

Hofmann, V., \& Stokburger-Sauer, N. E. (2017). The impact of emotional labor on employees' work-life balance perception and commitment: A study in the hospitality industry. International Journal of Hospitality Management, 65, 47-58.

Holman, D., Martınez-Inigo, D., \& Totterdell, P. (2008). Emotional labour and employee wellbeing: An integrative review. In N. M. Ashkanasy, \& C. L. Cooper (Eds.), Research 
companion to emotion in organizations (pp. 301-315). Northampton, MA: Edward Elgar.

*Hülsheger, U. R., Lang, J. W., Schewe, A. F., \& Zijlstra, F. R. (2015). When regulating emotions at work pays off: A diary and an intervention study on emotion regulation and customer tips in service jobs. Journal of Applied Psychology, 100(2), 263-277.

Hülsheger, U. R., \& Schewe, A. F. (2011). On the costs and benefits of emotional labor: A meta-analysis of three decades of research. Journal of Occupational Health Psychology, 16(3), 361-389.

Humphrey, R. H., Ashforth, B. E., \& Diefendorff, J. M. (2015). The bright side of emotional labor. Journal of Organizational Behavior, 36(6), 749-769.

Hunter, J.E., \& Schmidt, F.L. (2004). Methods of Meta-Analysis: Correcting Error and Bias in Research Findings. Thousand Oaks, CA: Sage.

*Hur, W. M., Moon, T. W., \& Han, S. J. (2014). The role of chronological age and work experience on emotional labor: The mediating effect of emotional intelligence. Career Development International, 19(7), 734-754.

*Hur, W. M., Moon, T. W., \& Jun, J. K. (2013). The role of perceived organizational support on emotional labor in the airline industry. International Journal of Contemporary Hospitality Management, 25(1), 105-123.

*Hur, W. M., Rhee, S. Y., \& Ahn, K. H. (2016). Positive psychological capital and emotional labor in Korea: The job demands-resources approach. The International Journal of Human Resource Management, 27(5), 477-500.

*Hwa, M. A. C. (2012). Emotional labor and emotional exhaustion: Does co-worker support matter? Journal of Management Research, 12(3), 115-127.

Jak, S. (2015). Meta-Analytic Structural Equation Modelling. Dordrecht, Neth: Springer.

Jak, S., \& Cheung, M. W. L. (2018). Accounting for missing correlation coefficients in fixedeffects MASEM. Multivariate Behavioral Research, 53(1), 1-14.

*Jeon, A. (2016). The effect of pre-flight attendants' emotional intelligence, emotional labor, and emotional exhaustion on commitment to customer service. Service Business, 10(2), 345-367.

*Jung, H. S., \& Yoon, H. H. (2014). Moderating role of hotel employees' gender and job position on the relationship between emotional intelligence and emotional labor. International Journal of Hospitality Management, 43, 47-52. 
Kammeyer-Mueller, J. D., Rubenstein, A. L., Long, D. M., Odio, M. A., Buckman, B. R., Zhang, Y., \& Halvorsen-Ganepola, M. D. K. (2013). A meta-analytic structural model of dispositonal affectivity and emotional labor. Personnel Psychology, 66(1), 47-90.

Karatepe, O. M. (2013). The effects of work overload and work-family conflict on job embeddedness and job performance: The mediation of emotional exhaustion. International Journal of Contemporary Hospitality Management, 25(4), 614-634.

Karatepe, O. M., Haktanir, M., \& Yorganci, I. (2010). The impacts of core self-evaluations on customer-related social stressors and emotional exhaustion. The Service Industries Journal, 30(9), 1565-1579.

Karna, A., Richter, A., \& Riesenkampff, E. (2016). Revisiting the role of the environment in the capabilities-financial performance relationship: A meta-analysis. Strategic Management Journal, 37(6), 1154-1173.

*Kim, H. J. (2008). Hotel service providers' emotional labor: The antecedents and effects on burnout. International Journal of Hospitality Management, 27(2), 151-161.

*Kim, Y., \& Back, K. J. (2012). Antecedents and consequences of flight attendants' job satisfaction. The Service Industries Journal, 32(16), 2565-2584.

*Kim, W. G., Han, S. J., \& Kang, S. (2019). Individual and group level antecedents and consequence of emotional labor of restaurant employees. Journal of Human Resources in Hospitality \& Tourism, 18(2), 145-171.

*Kim, H. J., Hur, W. M., Moon, T. W., \& Jun, J. K. (2017). Is all support equal? The moderating effects of supervisor, coworker, and organizational support on the link between emotional labor and job performance. BRQ Business Research Quarterly, 20(2), 124-136.

*Kim, T., Yoo, J., Lee, G., \& Kim, J. (2012). Emotional intelligence and emotional labor acting strategies among frontline hotel employees. International Journal of Contemporary Hospitality Management, 24(7), 1029-1046.

Koeske, G. F., \& Koeske, R. D. (1993). A preliminary test of a stress-strain-outcome model for reconceptualizing the burnout phenomenon. Journal of Social Service Research, 17(3-4), 107-135.

*Krannitz, M. A., Grandey, A. A., Liu, S., \& Almeida, D. A. (2015). Workplace surface acting and marital partner discontent: Anxiety and exhaustion spillover mechanisms. Journal of Occupational Health Psychology, 20(3), 314-325. 
*Lam, W., \& Chen, Z. (2012). When I put on my service mask: Determinants and outcomes of emotional labor among hotel service providers according to affective event theory. International Journal of Hospitality Management, 31(1), 3-11.

*Lam, W., Huo, Y., \& Chen, Z. (2018). Who is fit to serve? Person-job/organization fit, emotional labor, and customer service performance. Human Resource Management, 57(2), 483-497.

Landis, R. S. (2013). Successfully combining meta-analysis and structural equation modeling: Recommendations and strategies. Journal of Business and Psychology, 28(3), 251-261.

*Lawson, K. M., Davis, K. D., Crouter, A. C., \& O’Neill, J. W. (2013). Understanding workfamily spillover in hotel managers. International Journal of Hospitality Management, 33, 273-281.

Lazarus, R. S. (1966). Psychological Stress and the Coping Process. New York, NY: McGrawHill.

*Lechner, A. T., \& Paul, M. (2019). Is this smile for real? The role of affect and thinking style in customer perceptions of frontline employee emotion authenticity. Journal of Business Research, 94, 195-208.

*Lee, C., An, M., \& Noh, Y. (2015). The effects of emotional display rules on flight attendants' emotional labor strategy, job burnout and performance. Service Business, 9(3), 409-425.

*Lee, J. J., \& Ok, C. (2012). Reducing burnout and enhancing job satisfaction: Critical role of hotel employees' emotional intelligence and emotional labor. International Journal of Hospitality Management, 31(4), 1101-1112.

*Lee, J. J., \& Ok, C. M. (2014). Understanding hotel employees' service sabotage: Emotional labor perspective based on conservation of resources theory. International Journal of Hospitality Management, 36, 176-187.

*Lee, J. J., Ok, C. M., \& Hwang, J. (2016). An emotional labor perspective on the relationship between customer orientation and job satisfaction. International Journal of Hospitality Management, 54, 139-150.

*Lee, J., Ok, C. M., Lee, S. H., \& Lee, C. K. (2018). Relationship between emotional labor and customer orientation among airline service employees: Mediating role of depersonalization. Journal of Travel Research, 57(3), 324-341.

*Lee, L., \& Madera, J. M. (2019). Faking it or feeling it: The emotional displays of surface and deep acting on stress and engagement. International Journal of Contemporary Hospitality Management, 31(4), 1744-1762. 
*Li, J. J., Wong, I. A., \& Kim, W. G. (2017). Does mindfulness reduce emotional exhaustion? A multilevel analysis of emotional labor among casino employees. International Journal of Hospitality Management, 64, 21-30.

Liu, Y., Prati, L. M., Perrewe, P. L., \& Ferris, G. R. (2008). The relationship between emotional resources and emotional labor: An exploratory study. Journal of Applied Social Psychology, 38(10), 2410-2439.

*Luo, A., Guchait, P., Lee, L., \& Madera, J. M. (2019). Transformational leadership and service recovery performance: The mediating effect of emotional labor and the influence of culture. International Journal of Hospitality Management, 77, 31-39.

*Lv, Q., Xu, S., \& Ji, H. (2012). Emotional labor strategies, emotional exhaustion, and turnover intention: An empirical study of Chinese hotel employees. Journal of Human Resources in Hospitality \& Tourism, 11(2), 87-105.

*Medler-Liraz, H. (2014). Negative affectivity and tipping: The moderating role of emotional labor strategies and leader-member exchange. International Journal of Hospitality Management, 36, 63-72.

Mesmer-Magnus, J. R., DeChurch, L. A., \& Wax, A. (2012). Moving emotional labor beyond surface and deep acting: A discordance-congruence perspective. Organizational Psychology Review, 2(1), 6-53.

Michel, J. S., Kotrba, L.M., Mitchelson, J.K., Clark, M.A., \& Baltes, B.B. (2011). Antecedents of work-family conflict: A meta-analytic review. Journal of Organizational Behavior, 32(5), 689-725.

Nart, S., Sututemiz, N., Nart, S., \& Karatepe, O. M. (2019). Internal marketing practices, genuine emotions and their effects on hotel employees' customer-oriented behaviors. Journal of Human Resources in Hospitality \& Tourism, 18(1), 47-70.

*Newnham, M. P. (2017). A comparison of the enactment and consequences of emotional labor between frontline hotel workers in two contrasting societal cultures. Journal of Human Resources in Hospitality \& Tourism, 16(2), 192-214.

Nohe, C., Meier, L. L., Sonntag, K., \& Michel, A. (2015). The chicken or the egg? A metaanalysis of panel studies of the relationship between work-family conflict and strain. Journal of Applied Psychology, 100(2), 522-536.

*Okabe, N. (2017). Creating of customer loyalty by cabin crew: A study of the relation between emotional labor and job performance. Transportation Research Procedia, 25, 149-164. 
Ortiz-Bonnín, S., García-Buades, M. E., Caballer, A., \& Zapf, D. (2016). Supportive climate and its protective role in the emotion rule dissonance - emotional exhaustion relationship: A multilevel analysis. Journal of Personnel Psychology, 15(3), 125-133.

Payne, A., \& Frow, P. (2005). A strategic framework for customer relationship management. Journal of Marketing, 69(4), 167-176.

Podsakoff, P. M., MacKenzie, S. B., Lee, J. Y., \& Podsakoff, N. P. (2003). Common method biases in behavioral research: A critical review of the literature and recommended remedies. Journal of Applied Psychology, 88(5), 879-903.

Prati, L. M., Liu, Y., Perrewé, P. L., \& Ferris, G. R. (2009). Emotional intelligence as moderator of the surface acting-strain relationship. Journal of Leadership \& Organizational Studies, 15(4), 368-380.

*Prentice, C., Chen, P. J., \& King, B. (2013). Employee performance outcomes and burnout following the presentation-of-self in customer-service contexts. International Journal of Hospitality Management, 35, 225-236.

*Ramachandran, Y., Jordan, P. J., Troth, A. C., \& Lawrence, S. A. (2011). Emotional intelligence, emotional labour and organisational citizenship behaviour in service environments. International Journal of Work Organisation and Emotion, 4(2), 136-157.

*Rathi, N., Bhatnagar, D., \& Mishra, S. K. (2013). Effect of emotional labor on emotional exhaustion and work attitudes among hospitality employees in India. Journal of Human Resources in Hospitality \& Tourism, 12(3), 273-290.

Reeck, C., Ames, D. R., \& Ochsner, K. N. (2016). The social regulation of emotion: An integrative, cross-disciplinary model. Trends in Cognitive Sciences, 20(1), 47-63.

Richardson, K. M., \& Rothstein, H. R. (2008). Effects of occupational stress management intervention programs: A meta-analysis. Journal of Occupational Health Psychology, 13(1), 69-93.

Rusting, C. L., \& Larsen, R. J. (1997). Extraversion, neuroticism, and susceptibility to positive and negative affect: A test of two theoretical models. Personality and Individual Differences, 22(5), 607-612.

Schmeichel, B. J., Vohs, K. D., \& Baumeister, R. F. (2003). Intellectual performance and ego depletion: Role of the self in logical reasoning and other information processing. Journal of Personality and Social Psychology, 85(1), 33-46.

Schmidt, F. L., Hunter, J. E., Pearlman, K., Hirsh, H. R., ... \& Zedeck, S. (1985). Forty questions about validity generalization and meta-analysis. Personnel psychology, 38(4), 697-798. 
Scollon, C. N., \& Diener, E. (2006). Love, work, and changes in extraversion and neuroticism over time. Journal of Personality and Social Psychology, 91(6), 1152-1165.

*Shi, Y., \& Su, L. (2016). Hotel frontline employee's affective commitment and service creativity: the mediating effect of emotional labor. DEStech Transactions on Engineering and Technology Research.

*Shin, I., Hur, W. M., \& Oh, H. (2015). Essential precursors and effects of employee creativity in a service context: Emotional labor strategies and official job performance. Career Development International, 20(7), 733-752.

Smith, M. R., Rasmussen, J. L., Mills, M. J., Wefald, A. J., \& Downey, R. G. (2012). Stress and performance: Do service orientation and emotional energy moderate the relationship? Journal of Occupational Health Psychology, 17(1), 116-128.

*Sohn, H. K., \& Lee, T. J. (2012). Relationship between HEXACO personality factors and emotional labour of service providers in the tourism industry. Tourism Management, $33(1), 116-125$.

Sony, M., \& Mekoth, N. (2016). The relationship between emotional intelligence, frontline employee adaptability, job satisfaction and job performance. Journal of Retailing and Consumer Services, 30, 20-32.

*Tang, X. L., Gu, Y. K., \& Cui, L. (2017). Influence of leader and employee emotional labor on service performance: A hierarchical linear modeling approach. Social Behavior and Personality: An International Journal, 45(8), 1233-1244.

Totterdell, P., \& Holman, D. (2003). Emotion regulation in customer service roles: Testing a model of emotional labor. Journal of Occupational Health Psychology, 8(1), 55-73.

Tsaur, S.H., \& Tang, Y.Y. (2012). Job stress and well-being of female employees in hospitality: The role of regulatory leisure coping styles. International Journal of Hospitality Management, 31(4), 1038-1044.

*Üzümcü, T. P., Günsel, A., \& Yavaş, A. (2017). The consequences of internal marketing activities on emotional labor in tourism industry. Journal of Human Sciences, 14(2), 1909-1923.

Valentine, J. C., Pigott, T. D., \& Rothstein, H. R. (2010). How many studies do you need? A primer on statistical power for meta-analysis. Journal of Educational and Behavioral Statistics, 35(2), 215-247.

*Van Dijk, P. A., Smith, L. D., \& Cooper, B. K. (2011). Are you for real? An evaluation of the relationship between emotional labour and visitor outcomes. Tourism Management, $32(1), 39-45$. 
van Kleef, G. A. (2009). How emotions regulate social life: The emotions as social information (EASI) model. Current Directions in Psychological Science, 18(3), 184-188.

*Wang, C. (2019). From emotional labor to customer loyalty in hospitality. International Journal of Contemporary Hospitality Management. Advance online publication.

Wang, H., Hall, N. C., \& Taxer, J. L. (2019). Antecedents and consequences of teachers' emotional labor: A systematic review and meta-analytic investigation. Educational Psychology Review, 1-36.

Weiss, H.M., \& Cropanzano, R. (1996). Affective events theory: A theoretical discussion of the structure, causes and consequences of affective experiences at work. In B.M. Staw \& L.L. Commings (Eds.), Research in organizational behavior: An annual series of analytical essays and critical reviews, Vol. 18 (pp. 1-74). Greenwich, CT: Elsevier Science/JAI Press.

*Wen, J., Huang, S., \& Hou, P. (2019). Emotional intelligence, emotional labor, perceived organizational support, and job satisfaction: A moderated mediation model. International Journal of Hospitality Management, 81, 120-130.

Wong, C. S., \& Law, K. S. (2002). The effects of leader and follower emotional intelligence on performance and attitude: An exploratory study. The Leadership Quarterly, 13(3), 243-274.

*Wu, X., \& Shie, A. J. (2017). The relationship between customer orientation, emotional labour and job burnout. Journal of Chinese Human Resource Management, 8(2), 54-76.

*Wu, X., Shie, A. J., \& Gordon, D. (2017). Impact of customer orientation on turnover intention: Mediating role of emotional labour. International Journal of Organizational Analysis, 25(5), 909-927.

*Xu, S., Martinez, L. R., \& Lv, Q. (2017a). Explaining the link between emotional labor and turnover intentions: The role of in-depth communication. International Journal of Hospitality \& Tourism Administration, 18(3), 288-306.

*Xu, S., Martinez, L. R., \& Lv, Q. (2017b). Communication is key: The interaction of emotional labor strategies on hotel supervisors' turnover intentions in China. Tourism Analysis, 22(2), 125-137.

*Yagil, D., \& Medler-Liraz, H. (2017). Personally committed to emotional labor: Surface acting, emotional exhaustion and performance among service employees with a strong need to belong. Journal of Occupational Health Psychology, 22(4), 481-491. 
Yoo, J., \& Arnold, T. J. (2015). Frontline employee customer-oriented attitude in the presence of job demands and resources: The influence upon deep and surface acting. Journal of Service Research, 19(1), 102-117.

Zhao, X., Mattila, A.S., \& Ngan, N.N. (2014). The impact of frontline employees' work-family conflict on customer satisfaction: The mediating role of exhaustion and emotional displays. Cornell Hospitality Quarterly, 55(4), 422-432.

Zhou, J., \& George, J. M. (2003). Awakening employee creativity: The role of leader emotional intelligence. The Leadership Quarterly, 14(4-5), 545-568. 
Table 1 Characteristics of included studies

\begin{tabular}{|c|c|c|c|c|c|c|c|}
\hline Authors & $\begin{array}{l}\text { Country/regi } \\
\text { on }\end{array}$ & Sector & Participants & Sample size & Antecedents & Outcomes & $\begin{array}{l}\text { Strain as } \\
\text { mediator? (Y/N) }\end{array}$ \\
\hline $\begin{array}{l}\text { Abbas et al. } \\
\text { (2018) }\end{array}$ & Egypt & Hotel & Hotel employees & 173 & Supervisor support & Job satisfaction & $\mathrm{N}$ \\
\hline Aziz et al. (2016) & Malaysia & Aviation & Airline customers & 300 & & $\begin{array}{l}\text { Customer-oriented behaviour, } \\
\text { Service performance, } \\
\text { Customer loyalty }\end{array}$ & $\mathrm{N}$ \\
\hline Beal et al. (2013) & USA; Canada & Restaurant & Restaurant servers & 63 & & Strain & $\mathrm{N}$ \\
\hline $\begin{array}{l}\text { Bozionelos } \\
(2016)\end{array}$ & Saudi Arabia & Aviation & Flight attendants & 147 & & Job satisfaction & $\mathrm{N}$ \\
\hline $\begin{array}{l}\text { Bujisic et al. } \\
\text { (2014) }\end{array}$ & USA & Restaurant & Customers of restaurant & 278 & & Tip & $\mathrm{N}$ \\
\hline \multirow[t]{2}{*}{ Chen et al. (2012) } & China & Hotel & Hotel employees & 206 (Study 1) & & Job satisfaction & $\mathrm{Y}$ \\
\hline & & & $\begin{array}{l}\text { Hotel employees and } \\
\text { supervisors }\end{array}$ & 111 (Study 2) & & $\begin{array}{l}\text { Service performance, Job } \\
\text { satisfaction }\end{array}$ & $\mathrm{Y}$ \\
\hline Chen et al. (2019) & Taiwan & Restaurant & Restaurant employees & 260 & $\begin{array}{l}\text { Harmonious passion, } \\
\text { Obsessive passion }\end{array}$ & Emotional exhaustion & $\mathrm{N}$ \\
\hline $\begin{array}{l}\text { Chi \& Grandey } \\
\text { (2019) }\end{array}$ & Taiwan & Restaurant & Restaurant servers & 61 & & Service performance, CWB & $\mathrm{N}$ \\
\hline $\begin{array}{l}\text { Chi \& Wang } \\
\text { (2018) }\end{array}$ & Taiwan & Hotel & Hotel newcomers & 244 & & Service performance & $\mathrm{N}$ \\
\hline Chi et al. (2011) & USA & Restaurant & Restaurant servers & $\begin{array}{l}60 \text { employees, } \\
404 \text { customers }\end{array}$ & & Service performance, Tip & $\mathrm{N}$ \\
\hline Chu et al. (2012) & USA & Hotel & Hotel employees & 253 & $\begin{array}{l}\text { Affect, Emotional } \\
\text { contagion, Emotional } \\
\text { concern }\end{array}$ & $\begin{array}{l}\text { Job satisfaction, Emotional } \\
\text { exhaustion }\end{array}$ & $\mathrm{N}$ \\
\hline $\begin{array}{l}\text { Collishaw et al. } \\
\text { (2008) }\end{array}$ & Canada & Recreation & Fitness client & 132 & & Customer satisfaction & $\mathrm{N}$ \\
\hline Deng et al. (2017) & China & Hotel & Hotel employees & 150 & & CWB & $\mathrm{Y}$ \\
\hline $\mathrm{Fu}(2013)$ & Taiwan & Aviation & Flight attendants & 346 & & Customer-oriented behaviour & $\mathrm{N}$ \\
\hline Geng et al. (2014) & China & Restaurant & $\begin{array}{l}\text { Employee-supervisor } \\
\text { dyads }\end{array}$ & $\begin{array}{l}416 \\
\text { subordinates } \\
\text { and } 113 \\
\text { supervisors }\end{array}$ & & Creativity & $\mathrm{Y}$ \\
\hline \multirow{2}{*}{$\begin{array}{l}\text { Grandey et al. } \\
(2005)\end{array}$} & USA & Hotel & Students as customers & 114 (Study 1) & & Customer satisfaction & $\mathrm{N}$ \\
\hline & & Restaurant & Customers of restaurant & 255 (Study 2) & & Customer satisfaction & $\mathrm{N}$ \\
\hline
\end{tabular}




\begin{tabular}{|c|c|c|c|c|c|c|c|}
\hline Authors & Country/region & Sector & Participants & Sample size & Antecedents & Outcomes & $\begin{array}{l}\text { Strain as } \\
\text { mediator? (Y/N) }\end{array}$ \\
\hline $\begin{array}{l}\text { Gursoy et al. } \\
\text { (2011) }\end{array}$ & Turkey & Mixed & Hospitality students & 595 & $\begin{array}{l}\text { Extraversion, } \\
\text { Neuroticism }\end{array}$ & Job satisfaction & $\mathrm{N}$ \\
\hline Hameed (2016) & Pakistan & Hotel & Hotel employees & 471 & Big Five personality & Service performance & $\mathrm{Y}$ \\
\hline $\begin{array}{l}\text { Hülsheger et al. } \\
\text { (2015) }\end{array}$ & Netherlands & Restaurant & Restaurant servers & 166 & & Tip & $\mathrm{N}$ \\
\hline Hur et al. (2014) & South Korea & Aviation & Flight attendants & 256 & $\begin{array}{l}\text { Age, Work experience, } \\
\text { Emotional intelligence }\end{array}$ & & $\mathrm{N}$ \\
\hline Hur et al. (2013) & South Korea & Aviation & Flight attendants & 256 & $\begin{array}{l}\text { Perceived organisational } \\
\text { support }\end{array}$ & $\begin{array}{l}\text { Organisational commitment, } \\
\text { Turnover intention }\end{array}$ & $\mathrm{Y}$ \\
\hline Hur et al. (2016) & South Korea & Aviation & Flight attendants & 263 & $\begin{array}{l}\text { Psychological capital, } \\
\text { Justice }\end{array}$ & Turnover intention & $\mathrm{Y}$ \\
\hline Hwa (2012) & Malaysia & Hotel & Hotel employees & 137 & Coworker support & Emotional exhaustion & $\mathrm{N}$ \\
\hline Jeon (2016) & South Korea & Aviation & Flight attendants & 380 & Emotional intelligence & Customer-oriented behaviour & $\mathrm{Y}$ \\
\hline $\begin{array}{l}\text { Jung \& Yoon } \\
\text { (2014) }\end{array}$ & South Korea & Hotel & Hotel employees & 308 & Emotional intelligence & & $\mathrm{N}$ \\
\hline Kim (2008) & USA & Hotel & Hotel employees & 197 & $\begin{array}{l}\text { Extraversion, } \\
\text { Neuroticism, } \\
\text { Positive/negative display } \\
\text { rules }\end{array}$ & Burnout & $\mathrm{N}$ \\
\hline $\begin{array}{l}\text { Kim \& Back } \\
(2012)\end{array}$ & South Korea & Aviation & Flight attendants & 212 & & $\begin{array}{l}\text { Job satisfaction, Organisational } \\
\text { commitment }\end{array}$ & $\mathrm{Y}$ \\
\hline Kim et al. (2017) & South Korea & Aviation & Flight attendants & 119 & & Service performance & $\mathrm{N}$ \\
\hline Kim et al. (2012) & South Korea & Hotel & Hotel employees & 353 & Emotional intelligence & Service performance & $\mathrm{Y}$ \\
\hline Kim et al. (2019) & USA & Restaurant & $\begin{array}{l}\text { Restaurant } \\
\text { employees }\end{array}$ & 376 & Emotional intelligence & Service performance & $\mathrm{N}$ \\
\hline $\begin{array}{l}\text { Krannitz et al. } \\
(2015)\end{array}$ & USA & Hotel & Hotel managers & 197 & & Turnover intention & $\mathrm{Y}$ \\
\hline $\begin{array}{l}\text { Lam and Chen } \\
(2012)\end{array}$ & China & Hotel & Hotel employees & 424 & $\begin{array}{l}\text { Supervisor support, } \\
\text { Justice, Negative } \\
\text { emotion }\end{array}$ & $\begin{array}{l}\text { Job satisfaction, Service } \\
\text { performance, Turnover } \\
\text { intention }\end{array}$ & $\mathrm{N}$ \\
\hline Lam et al. (2018) & China & Hotel & Hotel employees & 263 & Person-job fit & $\begin{array}{l}\text { Service performance, Customer } \\
\text { satisfaction }\end{array}$ & $\mathrm{N}$ \\
\hline $\begin{array}{l}\text { Lawson et al. } \\
\text { (2013) }\end{array}$ & USA & Hotel & Hotel managers & 586 & & Work-family spillover & $\mathrm{N}$ \\
\hline $\begin{array}{l}\text { Lechner \& Paul } \\
(2017)\end{array}$ & Germany & Restaurant & $\begin{array}{l}\text { Students as } \\
\text { customers }\end{array}$ & 304 & & Customer satisfaction & $\mathrm{N}$ \\
\hline
\end{tabular}




\begin{tabular}{|c|c|c|c|c|c|c|c|}
\hline Authors & Country/region & Sector & Participants & $\begin{array}{l}\text { Sample } \\
\text { size }\end{array}$ & Antecedents & Outcomes & $\begin{array}{l}\text { Strain as } \\
\text { mediator? } \\
(\mathrm{Y} / \mathrm{N})\end{array}$ \\
\hline \multirow[t]{2}{*}{ Lee \& Madera (2019) } & USA & Hotel & Hotel managers & 140 & & Stress & $\mathrm{N}$ \\
\hline & & Mixed & Hotel students & 171 & & Stress & $\mathrm{N}$ \\
\hline Lee \& OK (2012) & USA & Hotel & Hotel employees & 309 & $\begin{array}{l}\text { Emotional } \\
\text { intelligence }\end{array}$ & Job satisfaction & $\mathrm{Y}$ \\
\hline Lee \& OK (2014) & USA & Hotel & Hotel employees & 309 & & CWB & $\mathrm{Y}$ \\
\hline Lee et al. (2018) & South Korea & Aviation & Flight attendants & 453 & & $\begin{array}{l}\text { Customer-oriented } \\
\text { behaviour }\end{array}$ & $\mathrm{Y}$ \\
\hline Lee et al. (2015) & South Korea & Aviation & Flight attendants & 230 & & $\begin{array}{l}\text { Burnout, Service } \\
\text { performance }\end{array}$ & $\mathrm{N}$ \\
\hline Lee et al. (2016) & USA & Hotel & Hotel employees & 309 & $\begin{array}{l}\text { Customer } \\
\text { orientation }\end{array}$ & Job satisfaction & $\mathrm{N}$ \\
\hline Li et al. (2017) & Macau & Gambling & Casino frontline employees & 526 & Mindfulness & Emotional exhaustion & $\mathrm{N}$ \\
\hline \multirow[t]{2}{*}{ Luo et al. (2019) } & USA (Study 1) & Mixed & Hospitality employees & 217 & $\begin{array}{l}\text { Transformational } \\
\text { leadership }\end{array}$ & Service performance & $\mathrm{N}$ \\
\hline & China (Study 2) & Mixed & Hospitality employees & 219 & $\begin{array}{l}\text { Transformational } \\
\text { leadership }\end{array}$ & Service performance & $\mathrm{N}$ \\
\hline Lv et al. (2012) & China & Hotel & Hotel employees & 185 & & Turnover intention & $\mathrm{Y}$ \\
\hline Medler-Liraz (2014) & Israel & Restaurant & Restaurant servers & 304 & & Tip & $\mathrm{N}$ \\
\hline \multirow[t]{2}{*}{ Newnham (2017) } & $\begin{array}{l}\text { Philippines } \\
\text { (Study 1) }\end{array}$ & Hotel & Hotel employees & 411 & & Burnout & $\mathrm{N}$ \\
\hline & $\begin{array}{l}\text { Australia (Study } \\
\text { 2) }\end{array}$ & Hotel & Hotel employees & 323 & & Burnout & $\mathrm{N}$ \\
\hline Okabe (2017) & Asia & Aviation & Cabin crew members & 413 & & Service performance & $\mathrm{Y}$ \\
\hline Prentice et al. (2013) & USA & Mixed & $\begin{array}{l}\text { Hospitality and tourism } \\
\text { employees }\end{array}$ & 578 & & $\begin{array}{l}\text { Burnout, Service } \\
\text { performance, OCB }\end{array}$ & $\mathrm{N}$ \\
\hline $\begin{array}{l}\text { Ramachandran et al. } \\
\text { (2011) }\end{array}$ & Malaysia & Hotel & Hotel employees & 131 & $\begin{array}{l}\text { Emotional } \\
\text { intelligence }\end{array}$ & OCB & $\mathrm{N}$ \\
\hline Rathi et al. (2013) & India & Hotel & Hotel employees & 204 & & $\begin{array}{l}\text { Emotional exhaustion, } \\
\text { Organisational } \\
\text { commitment, Turnover } \\
\text { intention }\end{array}$ & $\mathrm{N}$ \\
\hline Shi \& Su (2016) & China & Hotel & Hotel employees & 108 & $\begin{array}{l}\text { Organisational } \\
\text { commitment }\end{array}$ & Creativity & $\mathrm{N}$ \\
\hline
\end{tabular}




\begin{tabular}{|c|c|c|c|c|c|c|c|}
\hline Authors & $\begin{array}{l}\text { Country/regi } \\
\text { on }\end{array}$ & Sector & Participants & Sample size & Antecedents & Outcomes & $\begin{array}{l}\text { Strain as mediator? } \\
(\mathrm{Y} / \mathrm{N})\end{array}$ \\
\hline Shin et al. (2015) & South Korea & Aviation & Flight attendants & 119 & & $\begin{array}{l}\text { Creativity, } \\
\text { Service } \\
\text { performance }\end{array}$ & $\mathrm{Y}$ \\
\hline Sohn \& Lee (2012) & South Korea & Mixed & Mixed & 256 & $\begin{array}{l}\text { Big-five personality, } \\
\text { Honesty-humility, Display } \\
\text { rules }\end{array}$ & & $\mathrm{N}$ \\
\hline Tang et al. (2017) & China & Mixed & $\begin{array}{l}\text { Hotel, restaurant, } \\
\text { travel agency } \\
\text { employees }\end{array}$ & 534 & & $\begin{array}{l}\text { Service } \\
\text { performance }\end{array}$ & $\mathrm{N}$ \\
\hline Üzümcü et al. (2017) & Turkey & Hotel & Hotel employees & 136 & & $\begin{array}{l}\text { Job } \\
\text { satisfaction }\end{array}$ & $\mathrm{N}$ \\
\hline Van Dijk et al. (2011) & Australia & Tourism & $\begin{array}{l}\text { Visitors and tour } \\
\text { guides }\end{array}$ & $\begin{array}{l}688 \text { visitors and } \\
66 \text { tour guides }\end{array}$ & & $\begin{array}{l}\text { Customer } \\
\text { satisfaction }\end{array}$ & $\mathrm{N}$ \\
\hline Wang (2019) & Taiwan & Hotel & $\begin{array}{l}\text { Employee and } \\
\text { customer }\end{array}$ & $\begin{array}{l}1082 \text { employee- } \\
\text { customer dyad } \\
\text { responses }\end{array}$ & & $\begin{array}{l}\text { Service } \\
\text { performance } \\
\text { customer } \\
\text { loyalty }\end{array}$ & $\mathrm{N}$ \\
\hline Wen et al. (2019) & China & Hotel & Hotel employees & 279 & Emotional intelligence & $\begin{array}{l}\text { Job } \\
\text { satisfaction }\end{array}$ & $\mathrm{N}$ \\
\hline Wu \& Shie (2017) & China & Hotel & Hotel employees & 525 & Customer orientation & Burnout & $\mathrm{N}$ \\
\hline Wu et al. (2017) & China & Hotel & Hotel employees & 378 & Customer orientation & $\begin{array}{l}\text { Turnover } \\
\text { intention }\end{array}$ & $\mathrm{N}$ \\
\hline Xu et al. (2017b) & China & Hotel & Hotel supervisors & 144 & & $\begin{array}{l}\text { Turnover } \\
\text { intention }\end{array}$ & $\mathrm{N}$ \\
\hline Xu et al. (2017a) & China & Hotel & Hotel employees & 216 & & $\begin{array}{l}\text { Turnover } \\
\text { intention }\end{array}$ & $\mathrm{N}$ \\
\hline $\begin{array}{l}\text { Yagil \& Medler-Liraz } \\
\text { (2017) }\end{array}$ & Israel & Restaurant & $\begin{array}{l}\text { Restaurant } \\
\text { servers-customer } \\
\text { dyads } \\
\end{array}$ & 170 & Need to belong & $\begin{array}{l}\text { Customer } \\
\text { satisfaction }\end{array}$ & $\mathrm{Y}$ \\
\hline
\end{tabular}


Table 2 Relation between surface acting and antecedent/consequence variables

\begin{tabular}{|c|c|c|c|c|c|c|c|c|c|c|}
\hline \multirow{2}{*}{ Surface Acting } & \multirow[b]{2}{*}{$k$} & \multirow[b]{2}{*}{$N$} & \multirow[b]{2}{*}{$r$} & \multirow[b]{2}{*}{$S D r$} & \multirow[b]{2}{*}{$\rho$} & \multirow[b]{2}{*}{$S D \rho$} & \multicolumn{2}{|c|}{$95 \% C I$} & \multicolumn{2}{|c|}{$80 \% C V$} \\
\hline & & & & & & & Lower & Upper & Lower & Upper \\
\hline \multicolumn{11}{|l|}{ Correlation with antecedents } \\
\hline \multicolumn{11}{|l|}{ Personality } \\
\hline Extraversion & 4 & 984 & -0.087 & 0.088 & -0.087 & 0.060 & -0.225 & 0.052 & -0.185 & 0.012 \\
\hline Neuroticism (H1a) & 3 & 924 & 0.130 & 0.068 & 0.130 & 0.039 & -0.039 & 0.299 & 0.057 & 0.203 \\
\hline Emotional intelligence (H2a) & 10 & 3,614 & -0.077 & 0.151 & -0.077 & 0.141 & -0.185 & 0.031 & -0.272 & 0.119 \\
\hline Customer orientation (H3a) & 4 & 1,343 & -0.244 & 0.128 & -0.243 & 0.117 & -0.446 & -0.040 & -0.435 & -0.052 \\
\hline Social support (H4a) & 7 & 1,281 & -0.046 & 0.136 & -0.046 & 0.114 & -0.171 & 0.080 & -0.209 & 0.118 \\
\hline \multicolumn{11}{|l|}{ Display rules } \\
\hline Positive display rules & 2 & 453 & 0.068 & 0.028 & 0.067 & 0.000 & -0.185 & 0.319 & 0.067 & 0.067 \\
\hline Negative display rules (H5b) & 2 & 453 & 0.133 & 0.134 & 0.133 & 0.116 & -1.060 & 1.330 & -0.225 & 0.490 \\
\hline \multicolumn{11}{|l|}{ Correlation with outcomes } \\
\hline \multicolumn{11}{|l|}{ Attitudinal outcomes } \\
\hline Job satisfaction (H6a) & 11 & 2,559 & -0.144 & 0.217 & -0.143 & 0.207 & -0.289 & 0.002 & -0.428 & 0.141 \\
\hline Organisational commitment (H6b) & 5 & 1,369 & -0.072 & 0.131 & -0.072 & 0.116 & -0.234 & 0.091 & -0.250 & 0.107 \\
\hline Turnover intentions (H6c) & 8 & 2,004 & 0.387 & 0.265 & 0.386 & 0.259 & 0.165 & 0.607 & 0.019 & 0.752 \\
\hline \multicolumn{11}{|l|}{ Behavioural outcomes } \\
\hline Service performance (H8a) & 14 & 4,149 & -0.114 & 0.158 & -0.114 & 0.147 & -0.205 & -0.023 & -0.312 & 0.084 \\
\hline Creativity $(\mathrm{H} 8 \mathrm{~b})$ & 2 & 535 & -0.237 & 0.460 & -0.236 & 0.456 & -4.360 & 3.890 & -1.640 & 1.170 \\
\hline Customer-oriented behaviour $(\mathrm{H} 8 \mathrm{c})$ & 3 & 1,179 & 0.069 & 0.196 & 0.069 & 0.189 & -0.417 & 0.555 & -0.288 & 0.426 \\
\hline$O C B(\mathrm{H} 8 \mathrm{~d})$ & 2 & 709 & 0.075 & 0.044 & 0.075 & 0.000 & -0.320 & 0.470 & 0.075 & 0.075 \\
\hline$C W B(\mathrm{H} 8 \mathrm{e})$ & 3 & 520 & 0.262 & 0.173 & 0.261 & 0.158 & -0.169 & 0.691 & -0.037 & 0.559 \\
\hline \multicolumn{11}{|l|}{ Customer-related outcomes } \\
\hline Customer satisfaction (H10a) & 3 & 1,121 & -0.261 & 0.054 & -0.260 & 0.025 & -0.395 & -0.126 & -0.307 & -0.214 \\
\hline Tips (H11) & 1 & 304 & 0.150 & - & 0.150 & - & 0.040 & 0.260 & - & - \\
\hline
\end{tabular}

Notes: $C W B$, counterproductive workplace behaviour; $O C B$, organisational citizenship behaviour; $k$, number of samples; $N$, total number of participants; $r$, sample size weighted mean observed correlation; SD $r$, standard deviation of $r ; \rho$, mean correlation corrected for sampling error; SD $\rho$, standard deviation of $\rho$; $C I$, confidence interval; $C V$, credibility interval. The code within the parentheses indicates the corresponding hypothesis, for example, Hla represents Hypothesis la. 
Table 3 Relation between deep acting and antecedent/consequence variables

\begin{tabular}{|c|c|c|c|c|c|c|c|c|c|c|}
\hline \multirow{2}{*}{ Deep Acting } & \multirow[b]{2}{*}{$k$} & \multirow[b]{2}{*}{$N$} & \multirow[b]{2}{*}{$r$} & \multirow[b]{2}{*}{$S D r$} & \multirow[b]{2}{*}{$\rho$} & \multirow[b]{2}{*}{$S D \rho$} & \multicolumn{2}{|c|}{$95 \% C I$} & \multicolumn{2}{|c|}{$80 \% C V$} \\
\hline & & & & & & & Lower & Upper & Lower & Upper \\
\hline \multicolumn{11}{|l|}{ Correlation with antecedents } \\
\hline \multicolumn{11}{|l|}{ Personality } \\
\hline Extraversion $(\mathrm{H} 1 \mathrm{~b})$ & 4 & 984 & 0.211 & 0.063 & 0.211 & 0.014 & 0.111 & 0.311 & 0.188 & 0.234 \\
\hline Neuroticism & 3 & 924 & -0.068 & 0.091 & -0.068 & 0.071 & -0.294 & 0.158 & -0.202 & 0.066 \\
\hline Emotional intelligence $(\mathrm{H} 2 \mathrm{~b})$ & 9 & 3,305 & 0.261 & 0.129 & 0.260 & 0.120 & 0.161 & 0.360 & 0.093 & 0.427 \\
\hline Customer orientation (H3b) & 4 & 1,343 & 0.403 & 0.082 & 0.403 & 0.068 & 0.273 & 0.533 & 0.292 & 0.514 \\
\hline Social support (H4b) & 7 & 1,281 & 0.206 & 0.085 & 0.205 & 0.046 & 0.127 & 0.283 & 0.139 & 0.271 \\
\hline \multicolumn{11}{|l|}{ Display rules } \\
\hline Positive display rules (H5a) & 2 & 453 & 0.428 & 0.028 & 0.427 & 0.000 & 0.175 & 0.679 & 0.427 & 0.427 \\
\hline Negative display rules & 2 & 453 & 0.217 & 0.119 & 0.216 & 0.101 & -0.855 & 1.290 & -0.095 & 0.527 \\
\hline \multicolumn{11}{|l|}{ Correlation with outcomes } \\
\hline \multicolumn{11}{|l|}{ Attitudinal outcomes } \\
\hline Job satisfaction $(\mathrm{H7a})$ & 10 & 2,347 & 0.201 & 0.141 & 0.201 & 0.125 & 0.101 & 0.301 & 0.028 & 0.375 \\
\hline Organisational commitment $(\mathrm{H} 7 \mathrm{~b})$ & 4 & 1,157 & 0.054 & 0.191 & 0.054 & 0.182 & -0.250 & 0.358 & -0.243 & 0.352 \\
\hline Turnover intentions $(\mathrm{H} 7 \mathrm{c})$ & 7 & 1,926 & -0.174 & 0.193 & -0.174 & 0.183 & -0.352 & 0.004 & -0.438 & 0.090 \\
\hline \multicolumn{11}{|l|}{ Behavioural outcomes } \\
\hline Service performance (H9a) & 14 & 4,149 & 0.255 & 0.206 & 0.255 & 0.199 & 0.136 & 0.374 & -0.013 & 0.523 \\
\hline Creativity (H9b) & 2 & 535 & 0.212 & 0.189 & 0.212 & 0.179 & -1.480 & 1.910 & -0.340 & 0.763 \\
\hline Customer-oriented behaviour $(\mathrm{H} 9 \mathrm{c})$ & 3 & 1,179 & 0.560 & 0.189 & 0.559 & 0.185 & 0.091 & 1.030 & 0.210 & 0.908 \\
\hline$O C B(\mathrm{H} 9 \mathrm{~d})$ & 2 & 709 & 0.072 & 0.154 & 0.072 & 0.145 & -1.310 & 1.460 & -0.373 & 0.517 \\
\hline$C W B(\mathrm{H} 9 \mathrm{e})$ & 2 & 211 & -0.023 & 0.161 & -0.023 & 0.128 & -1.470 & 1.420 & -0.416 & 0.370 \\
\hline \multicolumn{11}{|l|}{ Customer-related outcomes } \\
\hline Customer satisfaction $(\mathrm{H} 10 \mathrm{~b})$ & 2 & 951 & 0.363 & 0.063 & 0.362 & 0.049 & -0.206 & 0.931 & 0.211 & 0.514 \\
\hline Tips (H11) & 2 & 470 & 0.265 & 0.143 & 0.264 & 0.128 & -1.010 & 1.540 & -0.131 & 0.659 \\
\hline
\end{tabular}


Table 4 Summary of hypotheses

\section{Hypothesis}

Supported? (Y/N)

1a: Neuroticism is positively related to surface acting. $\mathrm{Y}$

$1 \mathrm{~b}$ : Extraversion is positively related to deep acting. $\mathrm{Y}$

2a: Emotional intelligence is negatively related to surface acting. $\mathrm{N}$

$2 \mathrm{~b}$ : Emotional intelligence is positively related to deep acting. $\mathrm{Y}$

3a: Customer orientation is negatively related to surface acting. $\quad Y$

3b: Customer orientation is positively related to deep acting. $\quad \mathrm{Y}$

4a: Social support is negatively related to surface acting. $\quad \mathrm{N}$

4b: Social support is positively related to deep acting. $\quad \mathrm{Y}$

5a: Positive display rules are positively related to deep acting. $\quad$ Y

5b: Negative display rules are positively related to surface acting. $\quad$ Y

6a: Surface acting is negatively related to job satisfaction. $\quad Y$

6b: Surface acting is negatively related to organisational commitment. $\quad \mathrm{N}$

6c: Surface acting is positively related to turnover intentions. $\quad$ Y

7a: Deep acting is positively related to job satisfaction. $\quad Y$

7b: Deep acting is positively related to organisational commitment. $\quad \mathrm{N}$

7c: Deep acting is negatively related to turnover intentions. $\quad \mathrm{Y}$

8a: Surface acting is negatively related to service performance. $\quad \mathrm{Y}$

8b: Surface acting is negatively related to creativity. $\quad Y$

8c: Surface acting is negatively related to customer-oriented behaviour. $\quad \mathrm{N}$

$8 \mathrm{~d}$ : Surface acting is negatively related to OCB. $\quad \mathrm{N}$

8e: Surface acting is positively related to CWB. $\quad \mathrm{Y}$

9a: Deep acting is positively related to service performance. $\quad \mathrm{Y}$

9b: Deep acting is positively related to creativity. $\quad Y$

9c: Deep acting is positively related to customer-oriented behaviour. $\quad \mathrm{Y}$

9d: Deep acting is positively related to OCB. $\quad \mathrm{N}$

9e: Deep acting is negatively related to CWB. $\quad \mathrm{N}$

10a: Surface acting is negatively related to customer satisfaction. $\quad$ Y

10b: Deep acting is positively related to customer satisfaction. $\quad Y$

11: The relationship between deep acting and tipping is stronger than that of surface $\quad Y$ acting and tipping.

12a: Surface acting is positively related to strain. $\quad Y$

$12 \mathrm{~b}$ : Deep acting is negatively related to strain. $\quad \mathrm{Y}$

13: Strain mediates the relation between emotional labour strategies and the outcomes. $\quad \mathrm{Y}$ 
Antecedent to

Emotional labour

Dispositional antecedents:
Personality (extraversion,
neuroticism)
Emotional intelligence
Customer orientation
Contextual antecedents:
Social support
Display rules

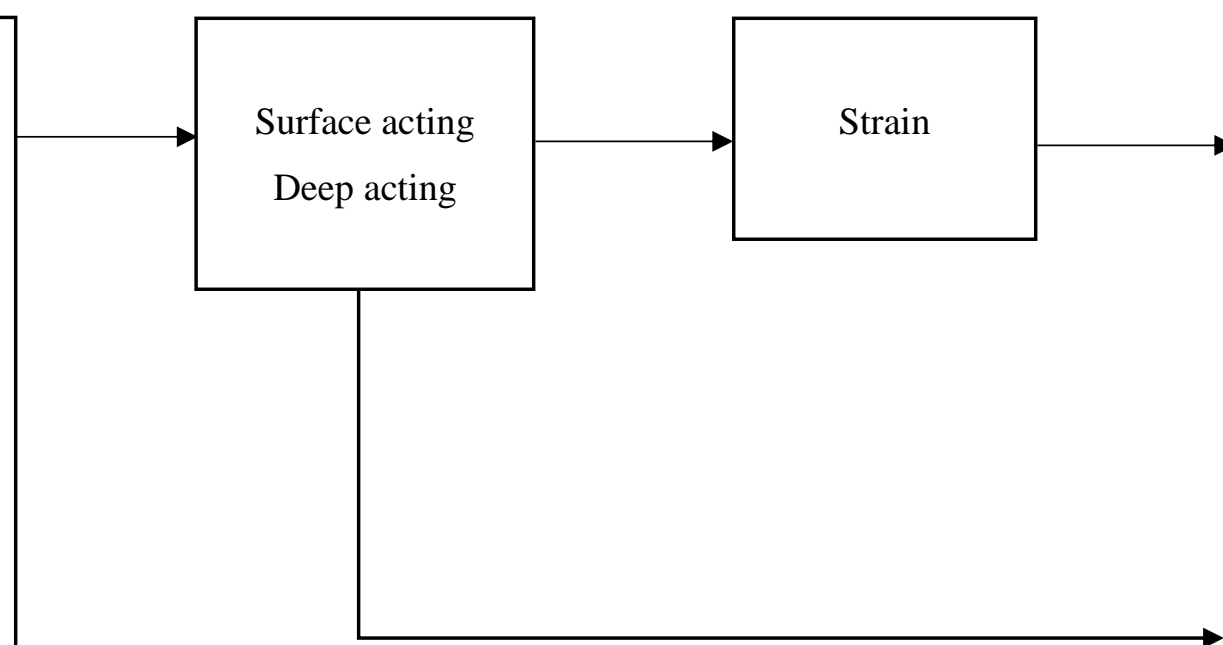

Attitudinal outcomes:

Job satisfaction

Organisational commitment

Turnover intentions

\section{Behavioural outcomes or performance:}

Service performance

CWB

Creativity

OCB

Customer-oriented behaviour

\section{Customer-related outcomes:}

Customer satisfaction

Tips

Figure 1. Conceptual model. 


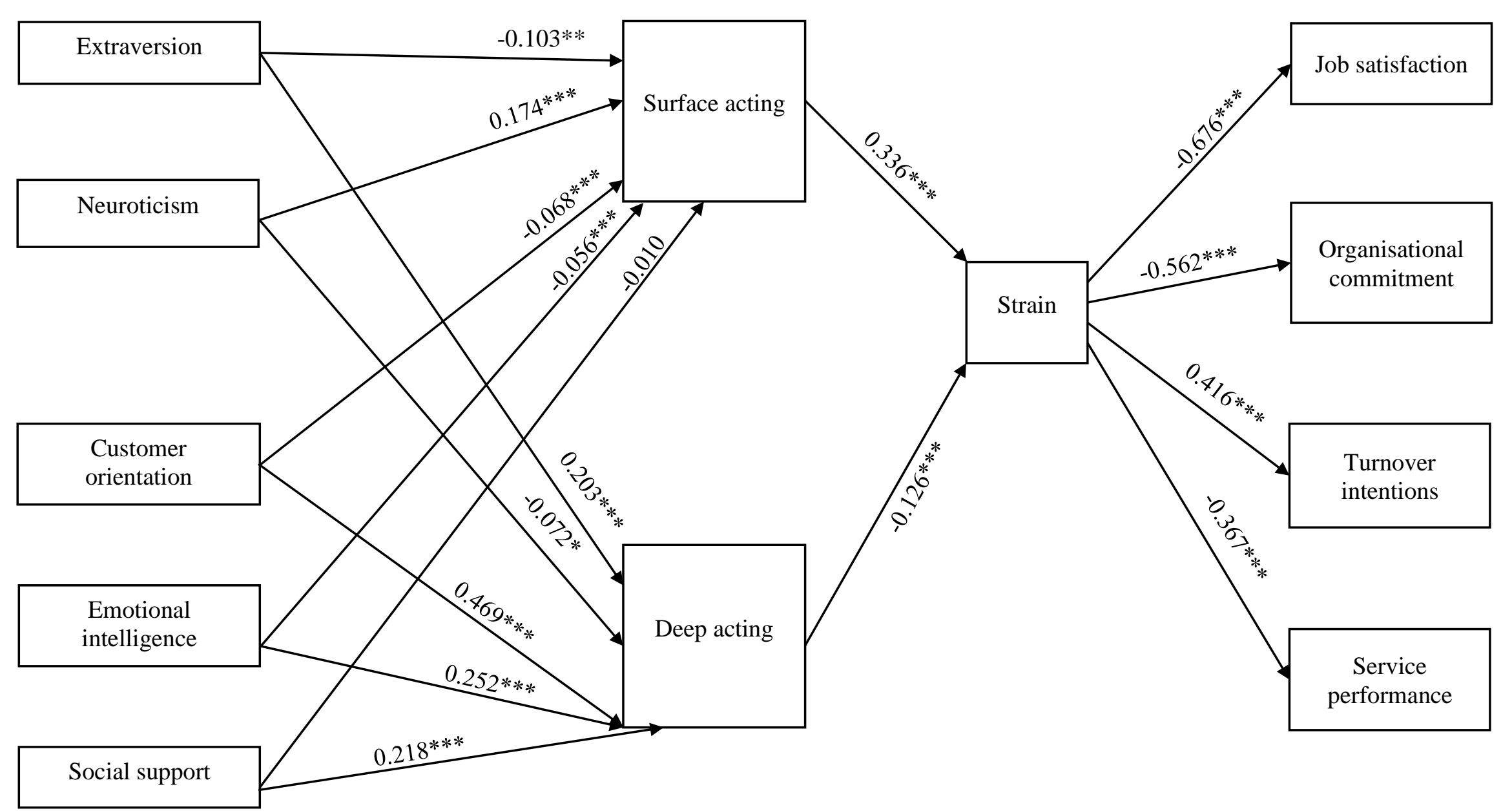

Figure 2. Causal relation between emotional labour and antecedents and outcomes through strain

Note: $* * * p<0.001 ; * * 0.001 \leq p<0.01 ; * 0.01 \leq p<0.05$. Hypotheses $12 a, 12 b$ and 13 are supported by results shown in this figure. 